\title{
Phosphorylation- and ubiquitin-dependent degradation of the cyclin-dependent kinase inhibitor Farlp in budding yeast
}

\author{
Sandra Henchoz, ${ }^{1}$ Yong Chi, ${ }^{2}$ Barbara Catarin, ${ }^{1}$ Ira Herskowitz, ${ }^{3}$ Raymond J. Deshaies, ${ }^{2}$ and \\ Matthias Peter ${ }^{\mathbf{1}, \mathbf{3}, \mathbf{4}}$ \\ ${ }^{1}$ Institut Suisse de Rechereches Expérimentales sur le Cancer (ISREC), 1066 Epal inges/VD Switzerland; ${ }^{2}$ California Institute \\ of Technology, Division of Biology, Pasadena, California 91125 USA; ${ }^{3}$ Department of Biochemistry and Biophysics, \\ University of California at San Francisco, San Francisco, California 94143-0448 USA
}

Cyclin-dependent kinase inhibitors (CKIs) play key roles in controlling the eukaryotic cell cycle by coordinating cell proliferation and differentiation. Understanding the roles of CKIs requires knowledge of how they are regulated both through the cell cycle and in response to extracellular signals. Here we show that the yeast CKI, Farlp, is controlled by ubiquitin-dependent proteolysis. Wild-type Farlp was stable only in the $G_{1}$ phase of the cell cycle. Biochemical and genetic evidence indicate that its degradation required the components of the $G_{1}-S$ ubiquitination system, Cdc34p, Cdk4p, Cdc53p, and Skplp. We isol ated a mutant form of Far1p (Far1p-22) that was able to induce cell cycle arrest in the absence of $\alpha$-factor. Cells that overexpress Far1-22p arrested in $G_{1}$ as large unbudded cells with low Cdc28p-CInp kinase activity. Wild-type Far1p, but not Far1-22p, was readily ubiquitinated in vitro in a C D C 34- and C D C 4-dependent manner. Far1-22p harbors a single amino acid change, from serine to proline at residue 87 , which alters phosphorylation by Cdc28p-CIn2p in vitro. Our results show that Far1p is regulated by ubiquitin-mediated proteolysis and suggest that phosphorylation of Far1p by the Codc28p-CInp kinase is part of the recognition signal for ubiquitination.

[Key Words: U biquitin; CKI; degradation; cell cycle; pheromone response; Far1p]

Received April 10, 1997; revised version accepted September 11, 1997.

The eukaryotic cell cycle is driven by the sequential activation and inactivation of cyclin-dependent kinases (Cdks) (N igg 1995). Cdks are composed of a catalytic subunit (Cdc28p in budding yeast) and a cyclin regulatory subunit (N asmyth 1993). The protein kinase activity of the complex is further regulated by specific phosphorylation of the catalytic subunit and by association with Cdk inhibitors (M organ 1995). CKIs have been identified in a variety of organisms, playing key roles during development, cell cycle regulation, and as effectors of checkpoint mechanisms (Sherr and Roberts 1995; Harper and Elledge 1996). Some of these inhibitory proteins are al so implicated in the development of cancer (Hunter and Pines 1994; Sherr 1996). Two CKIs have been identified in budding yeast Saccharomyces cerevisiae: $\mathrm{p} 40^{\mathrm{Sic} 1}$ regulates entry into S phase by inhibiting the Cdc28p-Clbp kinases (Mendenhall 1993; Schwob et al. 1994) and Farlp is specifical ly required to arrest the cell cycle in response to pheromones (Peter and Herskowitz 1994a). Mating pheromones activate a mitogen-activated protein (MAP) kinase signal transduction pathway that induces changes

${ }^{4}$ Corresponding author.

E-MAIL mathias.peter@isrec.unih.ch; FAX (41) 216526933. in gene transcription, alterations of cellular morphology, and cell cycle arrest in $G_{1}$ (Sprague and Thorner 1992; Herskowitz 1995; Leberer et al. 1997). Cell cycle arrest is mediated by Farlp, which functions as a CKI to inhibit the Cdc28p-CInp kinase (Peter and Herskowitz 1994b).

Despite the importance of CKIs, little is known about their regulation (Peter 1997). In the case of Farlp, the mRN A levels fluctuate through the cell cycle, peaking in $G_{1}$ (McKinney et al. 1993). Farlp levels increase severalfold in response to mating pheromones, and the protein becomes rapidly phosphorylated by the MAP kinase Fus3p (Peter et al . 1993). Although transcriptional induction of FAR 1 in response to pheromones is necessary to cause cell cycle arrest, it is not sufficient (Chang and Herskowitz 1992; Peter and Herskowitz 1994a), indicating that post-translational modification is also required to activate Farlp. The $\mathrm{CKI}$ p40 ${ }^{\mathrm{Sicl}}$ appears to be regulated through the cell cycle by ubiquitin-dependent degradation (Schwob et al. 1994). Likewise, the mammalian inhibitor p27 ${ }^{\mathrm{Kipl}}$ has been shown to be ubiquitinated in vitro and in vivo (Pagano et al. 1995).

Ubiquitin-dependent degradation of proteins has emerged as a key mechanism for regulating cell cycle transitions. Destruction is triggered by the covalent at- 
tachment of ubiquitin, which targets proteins for degradation by the proteasome (Ciechanover 1994; Hochstrasser 1996). At least two distinct ubi quitination complexes regulate cell cycle-dependent destruction of target proteins. Cdc16p, Cdc23p, and Cdc27p are part of a large multisubunit complex, termed anaphase promoting complex (APC), which is required for the onset of anaphase by degrading mitotic cyclins and as yet unknown proteins (King et al. 1996). Cdc34p, Cdc4p, Cdc53p, and Skplp are required for cells to enter $S$ phase, and cells lacking the function of any of these proteins arrest with a $G_{1}$ DNA content and an elongated bud ( $N$ asmyth 1996). CDC34 encodes a ubiquitin-conjugating enzyme (Goebl et al. 1988), whereas little information is available on the molecular function of the other proteins. $\mathrm{Cdc} 4 \mathrm{p}$ contains two sequence motifs found in many unrelated proteins: an F-box, which mediates the interaction with Skplp, and several WD40 repeats that may be important for the interaction with target proteins (Bai et al. 1996). U biquitin-dependent proteolysis of $\mathrm{p} 40^{\mathrm{Sic1}}$ appears to be crucial for cells to enter S phase (Schwob et al . 1994; Deshaies 1997). Although it is not yet understood how $\mathrm{p} 40^{\mathrm{Sicl}}$ is specifically recognized by the ubiquitination machinery, recent experiments suggest a role for phosphorylation by the Cdc28p-CInp kinase (Schneider et al. 1996; Tyers 1996).

To study the post-translational regulation of the CKI Far1p, we have isolated a mutant Farlp (Far1-22p), which arrests cells even in the absence of mating pheromones (Peter and Herskowitz 1994a). Whereas wild-type Farlp was only present in the $G_{1}$-phase, Far1-22p was found in the nucleus throughout the cell cycle. Our results strongly suggest that Far $1-22 p$ arrests cells in $G_{1}$ because it can no longer be ubiquitinated and degraded by the $\mathrm{G}_{1}-\mathrm{S}$ degradation system. Sequencing of Far1-22p revealed that the stabilizing mutation changed Serine 87
(Ser-87) to a proline residue. Interestingly, Ser-87 was located in a consensus phosphorylation site for Cdc28p kinase and could be specifically phosphorylated by Cdc28p-CIn2p in vitro. Our results show that Far1p is regulated by ubiquitin-dependent proteolysis, and suggest that an important determinant of the recognition signal for ubiquitination is a specific phosphorylation of Farlp by the Cdc28p-CInp kinase.

\section{Results}

Cells producing Far1-22p arrest their cell cycle by inhibiting the Cdc28p-CInp kinase in the absence of the mating pheromone pathway

Transcription of the CKI Farlp is induced severalfold in response to mating pheromones by a process that requires the transcriptional activator Ste12p (Chang and Herskowitz 1990; Oehlen et al. 1996). Transcriptional induction of Farlp, however, is not sufficient to cause cell cycle arrest: cells that produce wild-type Far1p from the inducible GAL1 promoter grow normally (Fig. 1; Chang and Herskowitz 1992). In an attempt to investigate the mechanism of the post-transcriptional activation of Far1p, we isolated an allele of FAR1 (FAR1-22) that was able to inhibit cell division in the absence of $\alpha$-factor (Fig. 1A). Cells expressing Far1-22p from the GAL1 promoter were unable to form colonies in the presence of galactose (which activates the GAL1 promoter), but grew normally on medium containing glucose (Fig. 1A,B; data not shown). To determine whether the function of Far $1-22 p$ requires basal activity of the mating pathway, growth inhibition was examined in a/ $\alpha$ diploid cells that are unable to respond to pheromones (Johnson 1995): Like haploid cells, a/ $\alpha$ diploids were inhibited by Far1-22p (Fig. 1A) showing that Far1-22p was

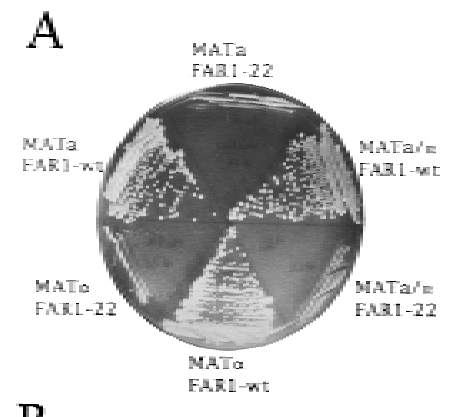

B

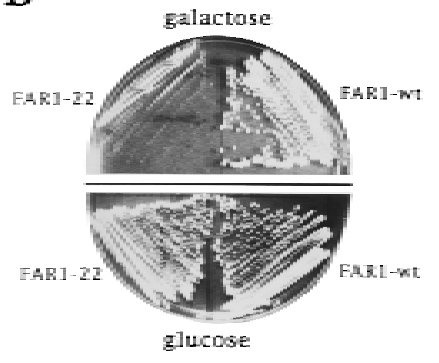

C

FAR1-22

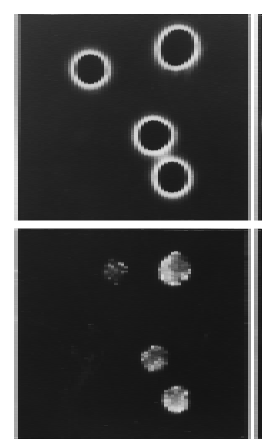

$\mathrm{D}$

FAR1-22

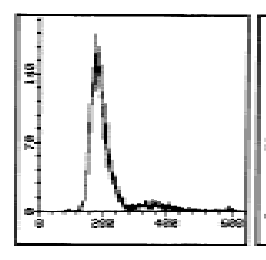

FAR1-wt

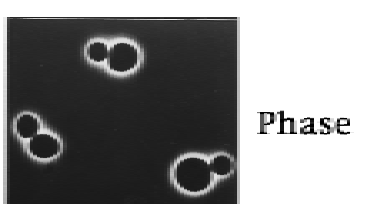

Actin

FAR 1-wt

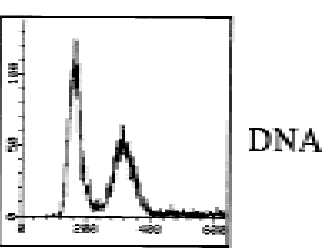

Figure 1. Cells producing Far1-22p arrest their cell cycle in $G_{1}$ independently of the mating pathway. (A) Haploid a (K699), $\alpha$ (K700), or a/ $\alpha$ diploid cells (Y M P562) were transformed with a plasmid expressing either wild-type Farlp or Far1-22p from the inducible GAL promoter and grown on medium containing galactose. N ote that cells expressing Far1-22p were unable to form colonies. (B) fus3s cells (K2297) that carry a plasmid coding for either wild-type Far1p or Far1-22p from the inducible GAL promoter were grown on media containing galactose (top, GAL promoter on) or glucose (bottom; GAL promoter off). (C,D) Cells expressing wild-type Farlp (YMP128, right panels) or Far1-22p (YMP126, left panels) from the inducible GAL promoter were analyzed $6 \mathrm{hr}$ after addition of galactose. (C) (Top) Phase-contrast photographs; (bottom) actin visualized after staining with rhodamine phalloidin. (D) Flow cytometric DNA quantification. 
able to prevent cell proliferation, not only in the absence of $\alpha$-factor, but also in cells lacking a functional pheromone response. Consistent with these results, Far1-22p inhibited proliferation of cells deleted for various components of the mating pathway such as FUS3 (Fig. 1B), STE11, or STE7 (data not shown).

$\mathrm{N}$ ext, we examined the phenotype of cells arrested by Far1-22p. After synthesis of Far1-22p was induced for 6 $\mathrm{hr}, \sim 90 \%$ of the cells accumulated as Iarge unbudded cells, indicating that they arrested in the $G_{1}$ phase of the cell cycle before bud emergence (Fig. 1C, top left). These cells contained predominantly one nucleus as visualized by 4', 6-diamidino-2-phenyl-inadole (DAPI) (data not shown) and a IN DN A content as determined by fluorescence-activated cell sorting (FACS) analysis (Fig. 1D). Staining the cells with rhodamine phalloidin revealed that the actin cytoskel eton was unpolarized, indicative of cells arrested at Start (Fig. 1C, bottom left panel). In contrast, cells producing wild-type Farlp continued to bud normally (Fig. 1C; top right panel) and displayed polarized actin (Fig. 1C, bottom right panel; Lew and Reed 1995). In addition, cells arrested by overexpression of Far1-22p were able to fully induce a FU S1-lacZ reporter construct in response to $\alpha$-factor (data not shown), suggesting that they were blocked in a mating-competent state (Oehlen and Cross 1994). Taken together, these observations suggest that cells producing Far1-22p arrest at Start in the $G_{1}$ phase of the cell cycle.

The transition from $G_{1}$ to $S$ phase requires activation of the $\mathrm{G}_{1}$ cyclin-dependent kinase $\mathrm{Cdc} 28 \mathrm{p}-\mathrm{CInp}$ ( $\mathrm{N}$ asmyth 1993). Whereas the Cdc28p catalytic subunit is present at constant levels throughout the cell cycle, the levels of the $G_{1}$ cyclins $C I n 1 p$ and $C I n 2 p$ peak as cells pass through Start (Koch and N asmyth 1994). Cells arrested by overexpression of Far1-22p contained high levels of $C \ln 2 p$ (Fig. 2B), showing that Far1-22p did not prevent synthesis of $C \ln 2 p$. In contrast, cells arrested by $\alpha$-factor repress transcription of CLN 1 and CLN2 (Wittenberg et al. 1990). Thus, our results indicate that repression of CLN 1 and CLN 2 transcription is not di rectly caused by Farlp, but rather by an $\alpha$-factor-induced event. In response to $\alpha$-factor, Farlp has been shown previously to bind directly and thereby inhibit the activity of Cdc28p associated with the $\mathrm{G}_{1}$-cyclins $\mathrm{CIn} 1 \mathrm{p}$ and $\mathrm{CIn} 2 \mathrm{p}$ (Peter and Herskowitz 1994b). As shown in Figure 2A, the histone $\mathrm{H} 1$ kinase activity associated with $\mathrm{CIn} 2 \mathrm{p}$
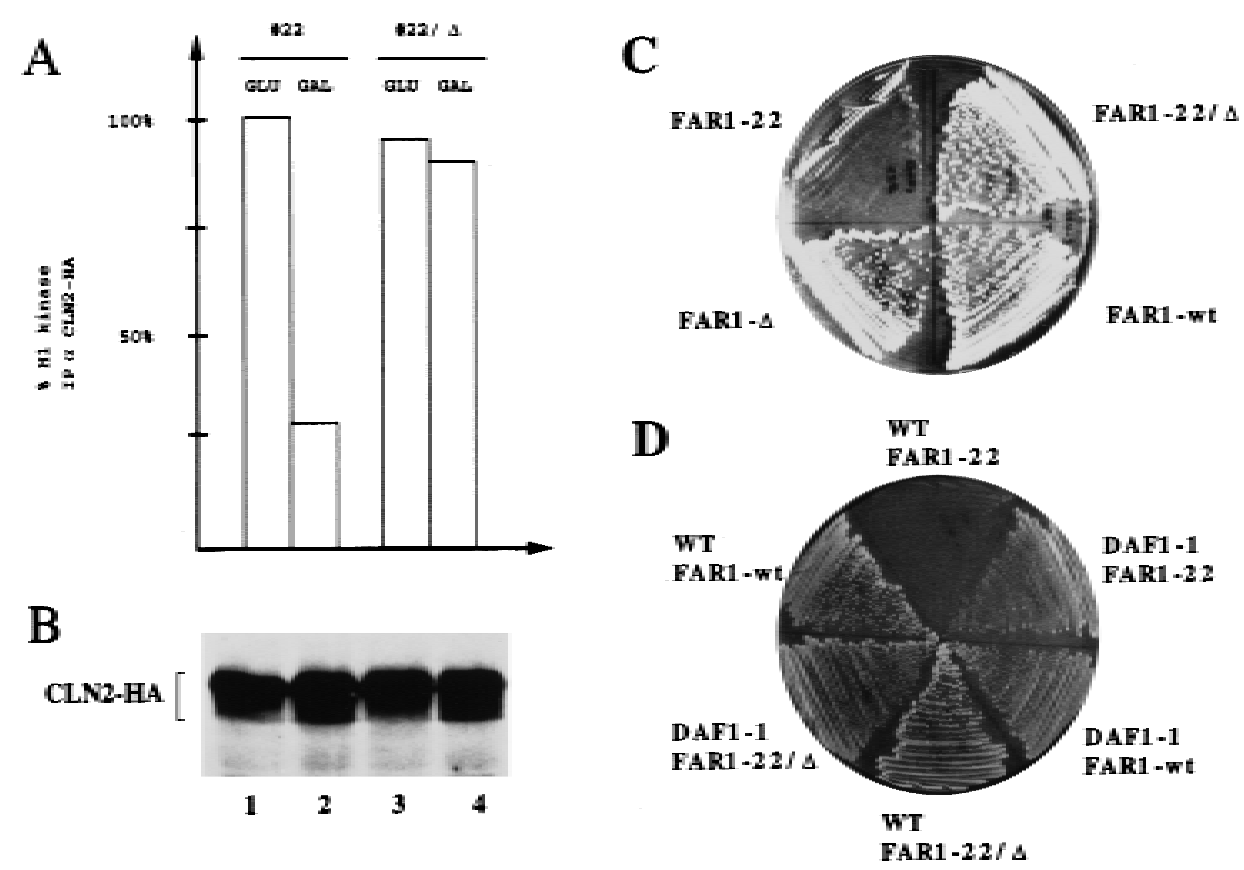

Figure 2. Cells producing Far1-22p arrest in $G_{1}$ by inhibition of the $G_{1}$ kinase, $C$ dc28p-CInp. (A,B) CIn2p tagged at its carboxyl terminus with three copies of the HA epitope (CIn2-HA) was immunoprecipitated from extracts prepared from cells (YMT263) expressing either Far1-22p or for control, an inactive mutant form of Far1p, Far1-22/ $\Delta 285-350$, from the inducible GAL promoter. Cells were grown in media containing gal actose (GAL, GAL promoter on) or glucose (GLU, GAL promoter off). CIn2-HAp-associated kinase activity was measured with histone $\mathrm{H} 1$ as a substrate and quantified (A). The kinase activity associated with $\mathrm{CIn} 2-\mathrm{HAp}$ from cells grown in glucose was normalized to $100 \%$. Similar amounts of $\mathrm{Cln} 2-\mathrm{HAp}$ were immunoprecipitated in each assay as shown by immunoblotting (B). (C) Growth inhibition caused by production of Far1-22p was dependent on the ability of Far1p to bind to the Cdc28p-CInp kinase. The following Far1p proteins were analyzed: wild-type Far1p, Far1-22p, Far1- $\Delta 285-350$, which is unable to bind to Cdc28p-CInp (Peter et al. 1993), and Far1-22/ $2285-350$. (D) Growth inhibition caused by expression of Far1-22p was rescued by co-overexpression of a stable $\mathrm{G}_{1}$-cyclin, CIn3p (DAF1). DAF1-1 cells (IH2517), which express a stable form of the $\mathrm{G}_{1}$ cyclin CIn3p or isogenic wild-type cells (IH 2518), were transformed with plasmids expressing either wild-type Far1p, Far1-22p, or Far1-22/ $\Delta 285-350 p$ from the inducible GAL promoter. 
was reduced in cells arrested with Far1-22p when compared with cells expressing either wild-type Farlp (data not shown) or an inactive mutant of Far1-22p (Far1-22/ $\Delta p)$. The $C \ln 2 p$-associated kinase activity was not reduced when synthesis of Far1-22p was not induced (Fig. $2 A)$. Binding of Far $1 p$ and $C d c 28 p$ requires a segment between amino acids 285 and 350 of Farlp (Peter et al. 1993). Cells producing Far1-22p del eted for this segment (Far1-22/ $\Delta$ p) failed to inhibit cell division (Fig. 2C), suggesting that binding of Far1-22p and C dc28p kinase was required to arrest the cell cycle. Finally, the effect of Far1-22p could be suppressed by high levels of $\mathrm{G}_{1}$-cyclins: Cells overexpressing a truncated form of Cln $3 p$ (Cross 1988) were able to grow in the presence of Far122p (Fig. 2D). Taken together, these results suggest that Far1-22p, at least in part, arrests cells at Start by inhibiting the Cdc28p-CInp kinase in the absence of $\alpha$-factor.

Far1-22p has an increased half-life and is stable throughout the cell cycle

The presence of wild-type Farlp is restricted to the $G_{1}$ phase of the cell cycle. This pattern is ensured by regulated transcription of FARI and by proteolysis (M CKinney and Cross 1995). Because we found that steady-state levels of Far1-22p were higher than wild-type Far1p (data not shown), we compared the stability of wild-type Farlp with Far1-22p. Both proteins were expressed from the
GAL1 promoter, at which time synthesis was turned off by addition of gl ucose. We observed rapid degradation of wild-type Farlp with a half-life of $\sim 30$ min (Fig. 3A,B). In contrast, Far1-22p remained stable throughout the time course (half-life $\sim 120 \mathrm{~min}$ ), showing that Far1-22p harbors a specific alteration that stabilizes the protein in vivo.

N ext, we examined whether Farlp was degraded in a cell cycle-dependent manner. To drive FAR1 transcription through the cell cycle, we expressed Farlp from the induci ble GAL1 promoter. Cells were arrested in S phase with hydroxyurea $(\mathrm{HU})$ or in mitosis with the microtubule depolymerizing drug nocodazole ( $\mathrm{N}$ oc). Synthesis of either wild-type Far1p or Far1-22p was then induced by addition of gal actose and analyzed by immunoblotting. Little wild-type Farlp could be detected in cells arrested in $\mathrm{S}$ phase or in mitosis (Fig. 3C). The remaining low levels of Farlp were most likely the result of incomplete cell cycle arrest (90\% arrest in both cases). In contrast, Far1-22p was present at high levels in both $S$ and $M$ phases of the cell cycle (Fig. 3C). The finding that Far1$22 p$ was present in a cell cycle-independent manner al so showed that FAR1 RNA was present throughout the cell cycle when driven from the GAL1 promoter. Thus, we conclude that wild-type Far1p, but not Far1-22p, was rapidly degraded at cell cycle stages other than $\mathrm{G}_{1}$. The degradation system for Far1p appears, therefore, to be active once cells pass through Start and remains active throughout the cell cycle until the cells exit from mitosis.
A

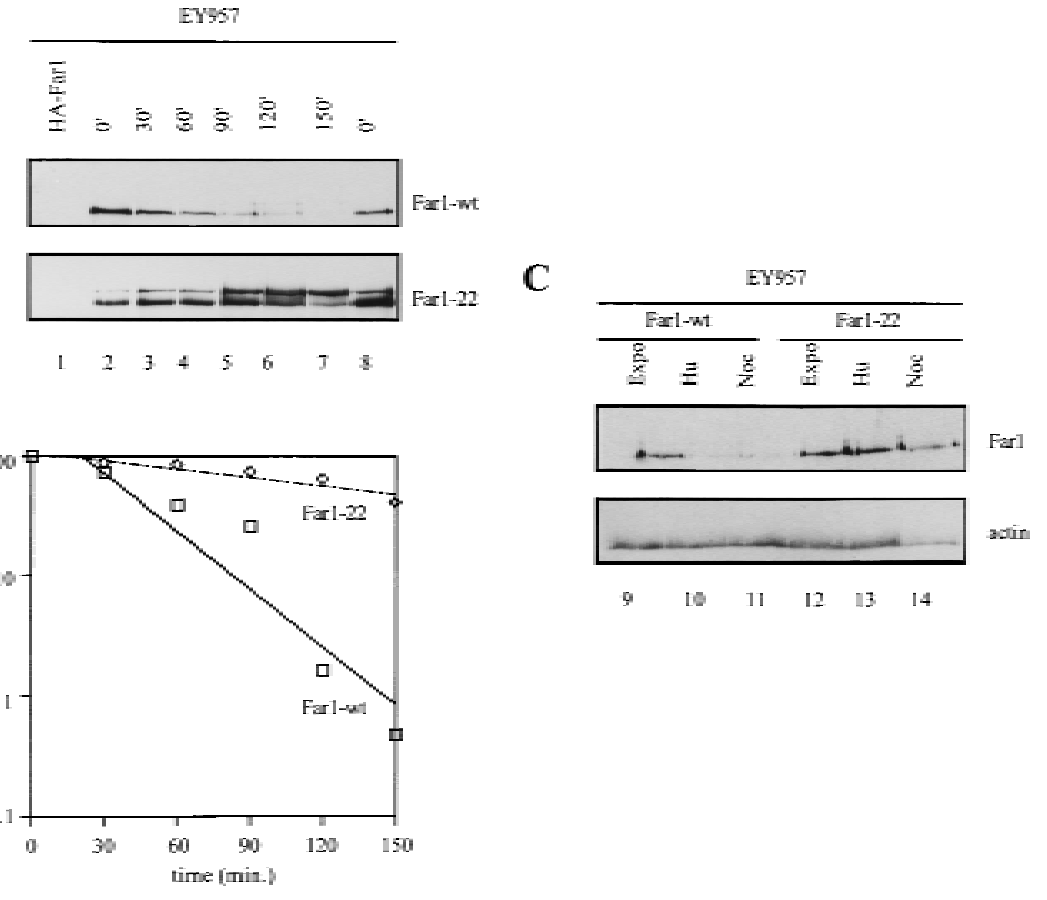

Figure 3. Far1-22p has an increased half-life and is present throughout the cell cycle. (A) Cells (K699) that carry a plasmid coding for either wild-type Far1-GFPp or Far1-22p-GFP from the inducible GAL promoter were grown in raffinose and expression was induced by addition of galactose for $5 \mathrm{hr}$. Glucose was then added to shut off the GAL promoter, and samples were taken every $30 \mathrm{~min}$ as indicated and immunoblotted for the presence of Far1-GFP fusion protein (lanes 1-8). The specificity of the GFP antibodies was confirmed by including cells expressing an HA-tagged version of Farlp (lane 1). (B) Quantitation of the GAL shutoff experiments. The degradation of wildtype Farlp-GFP and Far1-22-GFP proteins was quantified by Phosphorlmager and plotted against the time after repressing the GAL promoter. (C) Far122p, but not wild-type Farlp, is present throughout the cell cycle. EY957 cells producing wild-type Farlp-GFP (lanes 9-11) or Far1-22p-GFP (lanes 12-14) from the inducible GAL promoter were grown in medium containing raffinose (GAL promoter off), arrested in S phase with hydroxyurea (HU) or in mitosis with nocodazole (N oc), and then expression was induced by addition of gal actose. Control cells were treated identically except that they were not exposed to the drugs (expo). After $5 \mathrm{hr}$, cells were analyzed for the presence of Farlp-GFP by immunoblotting with antibodies specific for GFP (top panel). Equal loading was confirmed by immunoblotting the samples with antibodies against actin (bottom panel). 
We have also studied the presence of Farlp during the cell cycle by use of fusions of either wild-type Farlp or Far1-22p to the green fluorescent protein (GFP). The Far1p-GFP fusion protein was functional and able to restore both cell cycle arrest and mating competence to cells lacking Farlp (data not shown). As shown in Figure 4, wild-type Far1-GFP protein was readily visualized in the nucleus of unbudded $G_{1}$ cells, but very little Farlp was detected in cells that had passed Start (Fig. 4, top row). These results confirmed that wild-type Farlp was degraded after Start even when continuously expressed from the GAL1 promoter. Prolonged induction of Farl$22 p-G F P$ resulted in accumulation of the cells at Start. Far1-22p-GFP was visualized in the nucleus, showing that the stabilizing mutation that affects Far1-22p did not interfere with the subcellular local ization of the protein. Interestingly, however, Far1-22p-GFP was present in the nucleus of cells at all stages of the cell cycle (Fig. 4 , bottom row), confirming that Far1-22p was not degraded after cells passed Start.

Degradation of Farlp is required to efficiently re-enter the cell cycle after $\alpha$-factor arrest

To address the physiological significance of Farlp degradation, we asked whether degradation of Farlp was required for cells to re-enter the cell cycle after arrest by $\alpha$-factor. Cells deleted for FAR1, but producing Far1-22p from its own promoter, were able to grow normally because $\alpha$-factor is required for full transcriptional induction of FAR1 (Chang and Herskowitz 1990; Oehlen et al. 1996). These cells were hypersensitive to $\alpha$-factor, forming a halo that was larger than that of cells expressing wild-type Farlp (Fig. 5A, top panels), showing that Far1$22 p$ was functional. Interestingly, halos formed by cells expressing Far1-22p failed to fill in (Fig. 5A, bottom panel), indicating that these cells were unable to efficiently resume cell division. To further examine recovery from $\alpha$-factor arrest, far $1 \Delta$ cells producing either wild-type Farlp or Far1-22p were monitored microscopically as they synchronously re-entered the cell cycle. As shown in Figure 5 (B, open circles), cells producing wildtype Farlp started to bud after an initial lag phase, indicating that they resumed cell division and entered $\mathrm{S}$ phase. In contrast, cells producing nondegradable Far1$22 p$ failed to re-enter the cell cycle and remained unbudded (Fig. 5B, filled squares). Determination of Farlp levels by immunoblotting revealed that wild-type Farlp rapidly disappeared at the time of bud emergence (Fig. $5 B$ ), whereas Far $1-22 p$ remained constant and accumulated in slower migrating forms (Fig. 5C). This shift in mobility of Farlp was a consequence of phosphorylation, because incubation with alkaline phosphatase (CIP) eliminated the sl ower migrating forms (data not shown). Taken together, these results thus confirmed that Farlp was degraded when cells pass through Start and further indicated that degradation of Farlp is required for cells to efficiently re-enter the cell cycle after $\alpha$-factor arrest.

Farlp is stabilized in cells harboring temperature-sensitive alleles in components of the $\mathrm{G}_{1}-\mathrm{S}$ ubiquitination system

N ext, we examined whether Farlp degradation requires the $\mathrm{G}_{1}-\mathrm{S}$ degradation system. Because overexpression of Far1-22p, which cannot be degraded, causes cell cycle arrest, we reasoned that overexpression of wild-type Farlp in a cell that exhibited a reduced ability to degrade Farlp might similarly cause cell cycle arrest in $\mathrm{G}_{1}$. Consistent with this hypothesis, we found that overexpression of Farlp in a cdc34 mutant caused inviability at the semipermissive temperature (Fig. 6A). This effect was specific as wild-type cells or cells harboring a temperature-sensitive allele of CDC16, which is required to degrade mitotic cyclins (Irniger et al. 1995), grew normally when overexpressing Farlp. Examination of cdc34 cells overexpressing Farlp reveal ed that they arrested as large, unbudded cells ( $90 \%$ after $6 \mathrm{hr}$ of induction of Farlp by addition of galactose). In contrast, cdc34 mutant cells harboring control constructs accumulated prior to DNA replication with large el ongated buds (Fig. 6B, top row). Staining of the actin cytoskel eton with rhodamine phal-

\section{EY957}

G1

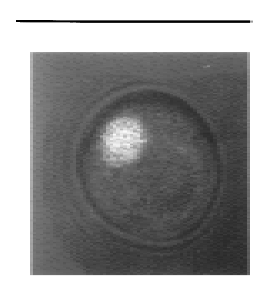

Figure 4. Wild-type Farlp, but not Far1$22 p$, is expressed in a cell cycle-dependent manner. Wild-type Farlp or Far1-22p was fused at its carboxyl terminus to GFP and produced in yeast (EY 957) from the inducible GAL promoter. N ote that wild-type Farlp-GFP (top row) was found in the nucleus of unbudded cells $\left(G_{1}\right)$, but staining disappeared in small budded cells $\left(\mathrm{G}_{1} /\right.$ $S)$, large budded cells $\left(G_{2} / M\right)$, and cells in mitosis (M). In contrast, Far1-22p-GFP (bottom row) could be detected in the nucleus of cells at all stages of the cell cycle.
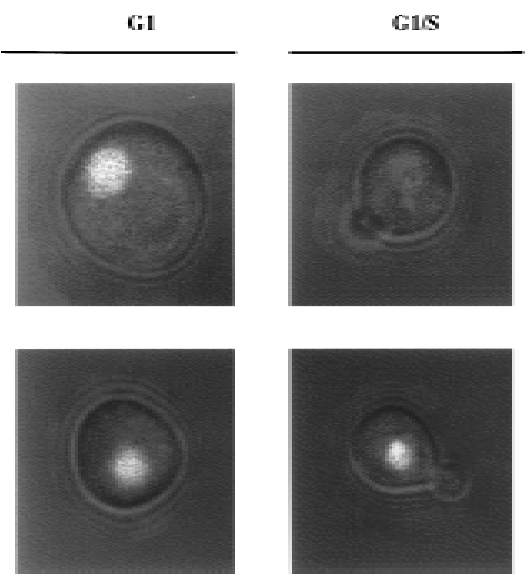
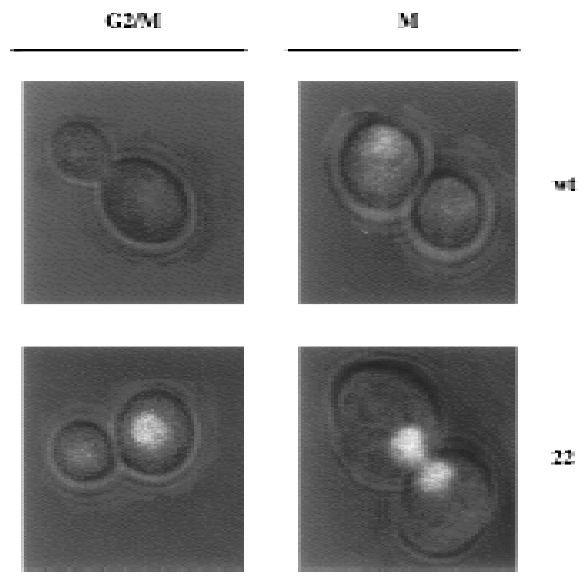

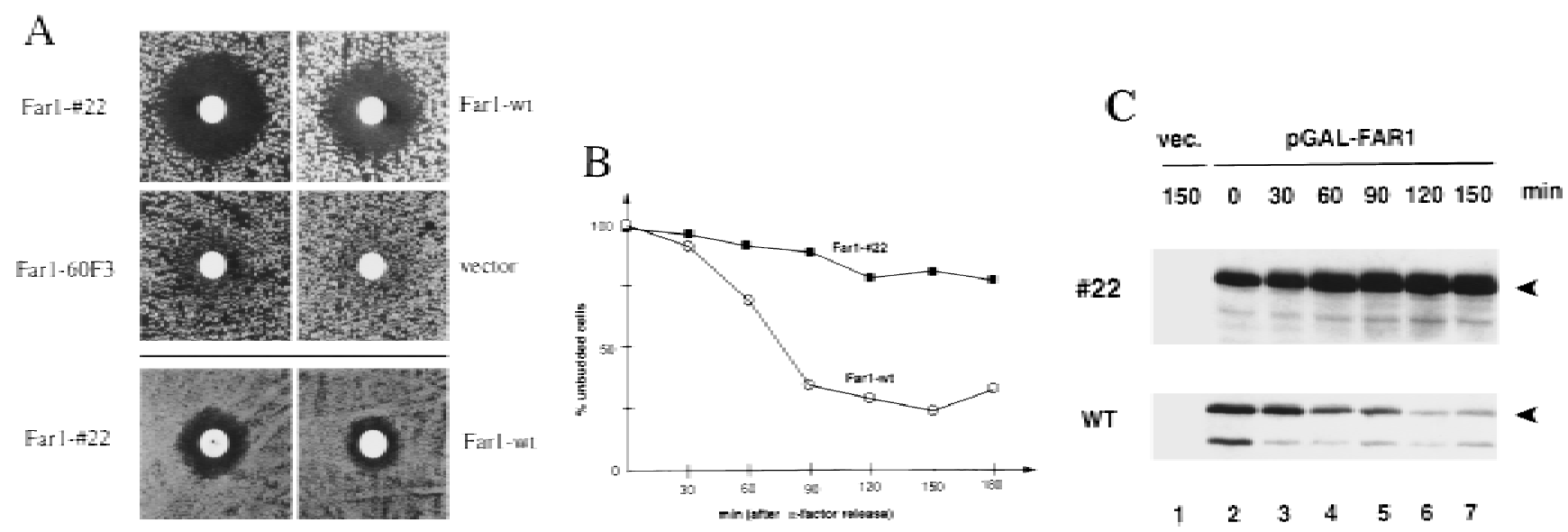

Figure 5. Degradation of Farlp is required for cells to recover efficiently from $\alpha$-factor induced cell cycle arrest. (A) cell cycle arrest was assayed by halo formation of far1 $1 \Delta$ cells transformed with single-copy plasmids carrying wild-type FAR1, FAR1-22, FAR1-60F3 (Peter et al. 1993), or no insert. (Top two rows) barl $\Delta$ cells (K2180), (bottom row) BAR $1^{+}$cells (YM P1054). Filter disks contain $0.1 \mu g$ (top two rows) and $10 \mu \mathrm{g}$ of $\alpha$-factor (bottom row). $N$ ote that cells producing Far1-22p are hypersensitive to pheromone and that hal os fill in inefficiently. (B,C) Cells producing Far1-22p are unable to re-enter the cell cycle. Cells deleted for FAR1 (K2180) producing wild-type Far1p or Far1-22p from the GAL promoter were grown in raffinose medium to an $\mathrm{OD}_{600}$ of 0.4 , at which time cells were arrested by the simultaneous addition of $\alpha$-factor and galactose. After $3 \mathrm{hr}$, cells were washed and reinoculated in fresh medium, without $\alpha$-factor, but containing galactose. Every $30 \mathrm{~min}$, samples were harvested. Re-entry into the cell cycle was monitored microscopically by analyzing the percentage of unbudded cells (B) Levels of wild-type Farlp (bottom panel) and Far1-22p (top panel) were determined after immunobl otting extracts with Farlp anti bodies ( $C$, lanes $1-7)$. $N$ ote that in contrast to cells producing wild-type Farlp, Far1-22p is accumulating in $\mathrm{G}_{1}$ and cells are unable to form a bud.

Ioidin showed that cdc34 cells producing Farlp were unpolarized, indicating that they were arrested at Start (Fig. $6 \mathrm{~B}$, bottom row). Thus, the morphology of these cells appeared indistinguishable from wild-type cells arrested by stabilized Far1-22p (Fig. 1C), suggesting that Far1p is degraded by a Cdc34p-dependent mechanism.

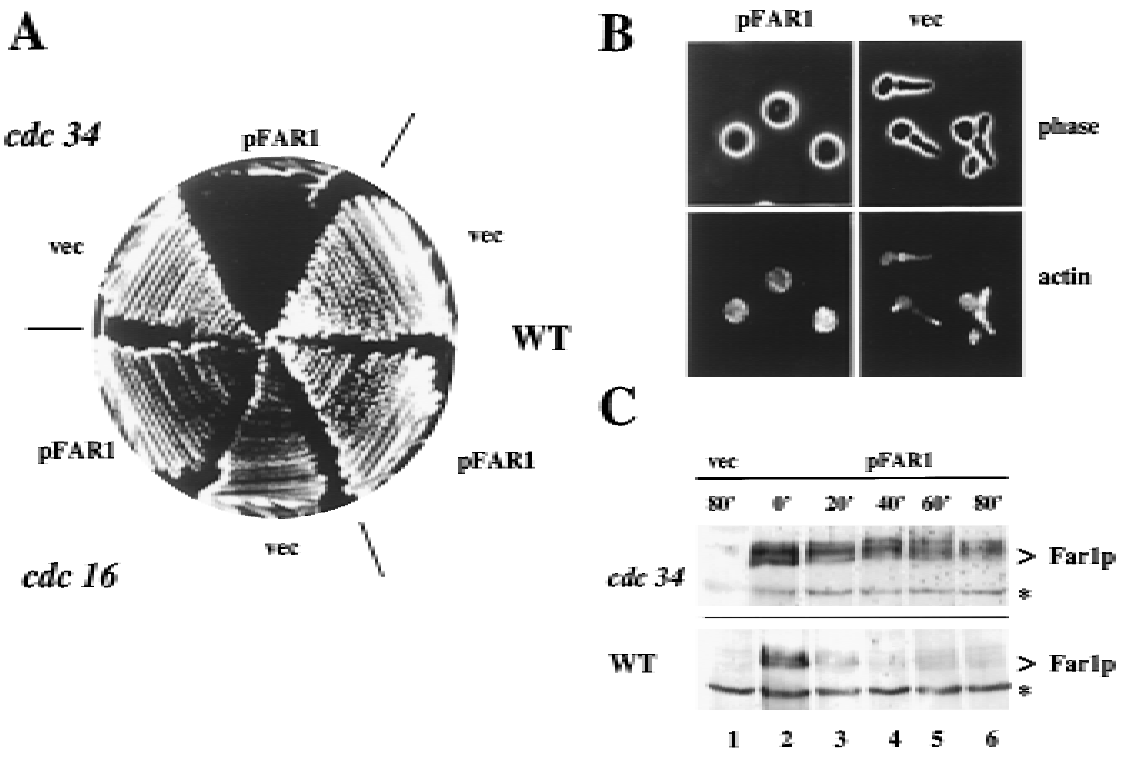

Figure 6. Overexpression of wild-type Farlp is lethal in cdc34 cells at the semipermissive temperature because of stabilization of the Far1 protein. (A) Temperature-sensitive cdc16 (K4102) and cdc34 (YMT670) mutants, as well as isogenic wild-type cells (K699), were transformed with a plasmid carrying wild-type FAR 1 under the control of the inducible GAL promoter or an empty vector (vec) for control. Transformants were plated on media containing galactose and incubated at $30^{\circ} \mathrm{C}$. Wild-type and cdc16 mutant strains tolerate overexpression of Farlp, whereas cdc34 mutants do not. All strains grew normally when plated on medium containing glucose (data not shown). (B) cdc34 cells (YMT670) carrying a plasmid expressing Farlp from the inducible GAL promoter (pFar1; left panels) or control plasmid with no insert (vec; right panels) were grown in raffinose at $30^{\circ} \mathrm{C}$, at which time expression of Farlp was induced by addition of galactose. After $5 \mathrm{hr}$, cells were fixed and analyzed by phase contrast microscopy (Phase, top panels) or after actin staining with rhodamine phal loidin (Actin, bottom panels). cdc34 cells producing Far1p arrest with a morphol ogy indistinguishable from that of wild-type cells producing Far1-22p (Fig. 1C). (C) The half-life of wild-type Far1p was determined in cdc34 far1 1 (top panel; Y M P1056) and farl $\Delta$ cells (bottom panel; Y M P1054), which express Far1p from the GAL promoter. After repression of the GAL promoter at the indicated times (minutes), aliquots were removed and examined by immunoblotting as described. The specificity of the Farlp anti bodies was confirmed by analysis of cells carrying an empty vector (vec; lane 1). The position of Farlp is marked by an arrowhead; the asterisks mark an unspecific protein recognized by the Farlp antiserum. 
In addition to Cdc34p, the CDC53, CDC4, and SKP1 gene products have also been implicated in the ubiquitin-dependent degradation of target proteins ( $\mathrm{N}$ asmyth 1996; Deshaies 1997). Overexpression of Far1p was lethal in any of these backgrounds at the semi-permissive temperature, suggesting that these components were required for degradation of Farlp (Fig. 7A; data not shown). Specific temperature-sensitive al leles of SKP1 that arrest cells either before DNA replication in $\mathrm{G}_{1}$ or before mitosis in $G_{2}$ (Bai et al. 1996; Connelly and Hieter 1996) have been identified. Interestingly, overexpression of Farlp was able to arrest cells harboring the $G_{1}$-specific allele of SKP1 but had no effect on cells harboring the $\mathrm{G}_{2}$-specific allele of SKP1 (Fig. 7A). Taken together, these results indicate that Farlp is degraded by the $G_{1}-S$ ubiquitination system involving the ubiquitin-conjugating enzyme Cdc34p and the proteins C dc53p, C dc $4 p$, and Skplp.

Consistent with the proposed role of Cdc34p in the degradation of Farlp, the half-life of wild-type Farlp was dramatically increased in cdc34 and cdc53 cells at the nonpermissive temperature (Fig. 6C; data not shown). To determine whether the cell cycle stage, rather than lack of Cdc34p function, accounted for the accumulation of Far1p, we analyzed Far1p level s in cdc34 cells that were simultaneously del eted for $\mathrm{SIC}$. These cells are able to replicate normally but arrest subsequently in $G_{2}$, presumably because they fail to degrade an as yet unknown target (Schwob et al. 1994). We expressed Far1p fused at its carboxyl terminus to LacZ from the inducible GAL promoter, which facilitated quantification of Far1p levels by a color assay (Barral et al. 1995). The Far1-LacZ fusion protein, like wild-type Farlp, was degraded in a cell cycle-dependent manner (Fig. 7B,C; B. Catarin and M. Peter, unpubl.). As expected, Farlp acccumulated in cdc34 cells, and was present at levels approximately three to fourfold higher than in isogenic wild-type cells or cells lacking SIC1 (Fig. 7B; M cKinney et al. 1993). Importantly, Farlp levels remained high in cdc34 sicls cells, whereas low levels of Far1p were detected in cdc16 cells, which arrest in mitosis. In contrast, the Far1-22LacZ fusion protein was present at higher levels than wild-type Far1-LacZ protein in both wild-type and cdc16 cells (Fig. 7C) whereas the levels of Far1-LacZp and Far122-LacZ $p$ were comparable when produced in cdc34 or cdc34 sicl $\Delta$ cells (Fig. 7C). Taken together, these results show that lack of Cdc34p itself, rather than arrest at a particular stage of the cell cycle, was responsible for the accumulation of Farlp.

In vitro ubiquitination of Far1p depends upon Cdc34p, Cdc4p, and cyclins

To determine whether Farlp is ubiquitinated by the $\mathrm{G}_{1}$-S ubiquitination system, we in vitro-translated Far1p in rabbit reticulocyte lysates (Fig. 8A) or wheat germ extracts (Fig. 8B) in the presence of ${ }^{35}$ S]methionine and added DEAE-fractionated yeast extracts (Verma et al. 1997a). These extracts are devoid of the $G_{1}$ cyclins CIn1p, CIn2p, and CIn3p and are depleted of Cdc34p (Fig. 8A) or lack functional Cdc4p (Fig. 8B). Addition of Far1p, purified GST-CIn2p, ubiquitin (Ub), and Cdc34p resulted in accumulation of slower migrating forms of Farlp (Fig. 8A, lane 2). Methylated ubiquitin (meUb), which blocks formation of multiubiquitin chains by preventing U b-Ub ligation (Hershko and Heller 1985), pre-
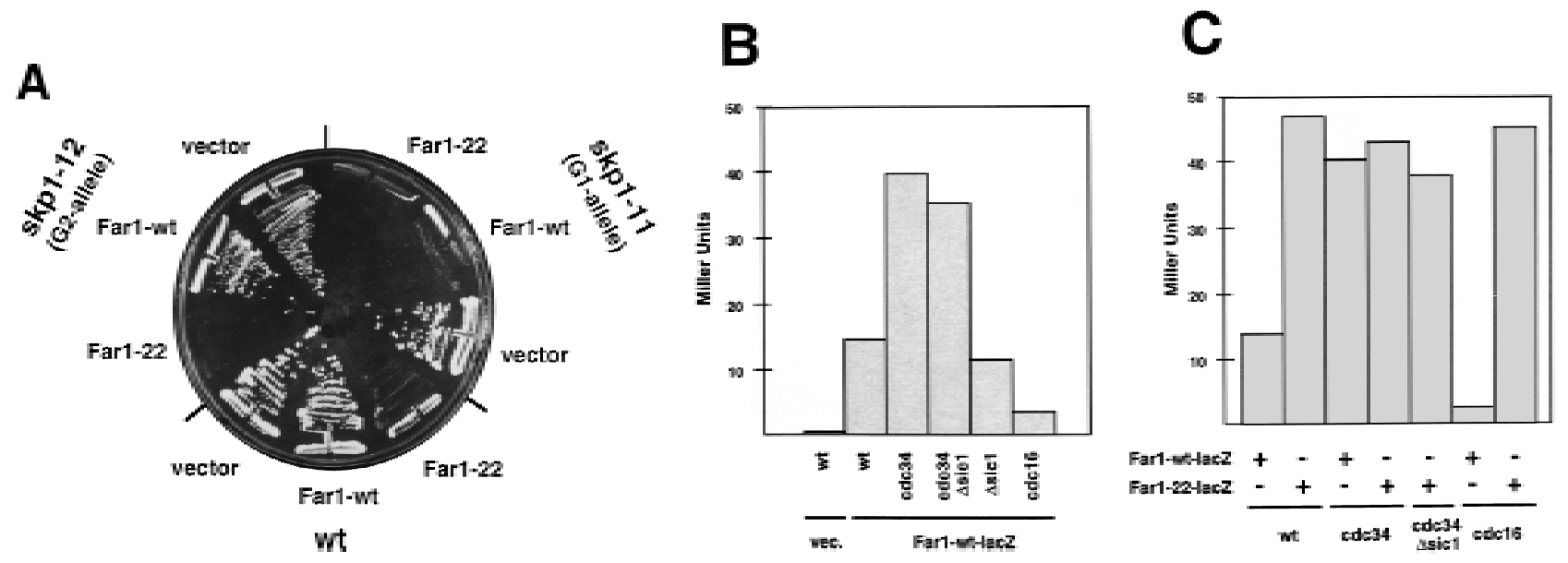

Figure 7. Overexpression of Farlp is lethal in skpl mutants in an allele-specific fashion and Farlp accumulates in cdc34 mutants independent of the cell cycle stage. (A) The effect of overexpression of Farlp was tested in specific temperature-sensitive allel es of SKP1

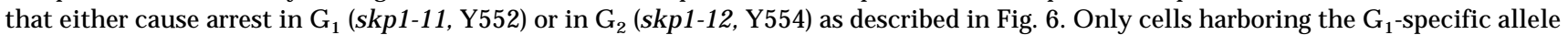
of SKP1 were arrested by overexpression of wild-type Far1p. (B) Far1p accumulates in cdc34 (YMT670) and cdc34 $\Delta$ sic1 cells (ES464). The indicated strains were arrested at $37^{\circ} \mathrm{C}$ and the accumulation of a Far1-LacZ fusion protein was quantified and plotted as Miller Units deduced from three independent experiments. N ote that Far1-LacZp accumulates in cdc34 mutants independently of the cell cycle arrest point; no accumulation was observed in cdc16 cells or cells deleted for SIC1. (C) Far1-22-LacZp accumulates in wild-type (K699) and cdc16 (K4102) mutant cells but is produced at levels similar to wild-type Far1-LacZp in cdc34 (Y M T670) and cdc34 $\Delta$ sic1 (ES464) cells. 
$\mathrm{A}$

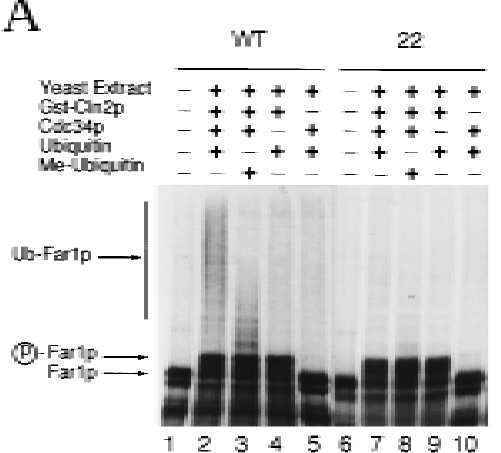

B

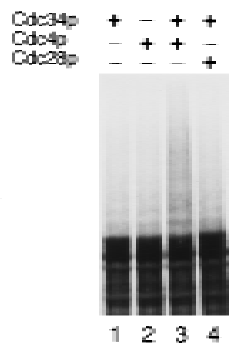

Figure 8. Wild-type Far1p but not Far1-22p is ubiquitinated in vitro. Wild-type Far1p (A, lanes 1-5; B, Ianes 1-4) or Far1-22p (A, lanes 6-10) synthesized in vitro in the presence of $\left[{ }^{35}\right.$ S]methionine was incubated in fractionated extracts prepared from cells lacking CLN 1,2, and 3 (A) or cells deleted for CLN 1,2, and 3, which are also temperature-sensitive for cdc4 (B). These extracts are devoid of Cdc34p and contain low levels of ubiquitin (Verma et al. 1997a). (A) Wild-type Farlp was ubiquitinated if the extract was supplemented with the addition of Cdc34p, GST-CIn2p, and ubiquitin (lane 2). Reduced accumulation of high molecular weight ubiquitin conjugates was observed if methyl-ubiquitin was added to block chain extension (lane 3). No ubiquitination was observed with Far1-22p (lanes 6-10). (B) Ubiquitination of wild-type Far1p was dependent on Cdc4p (lanes 1 and 4). Ubiquitination in cdc4-extracts was restored only by the simultaneous addition of purified Cdc34p and baculo-infected insect lysate containing C dc4p (lane 3). The addition of insect lysate containing Cdc28p serves as a specificity control (lane 4).

vented accumulation of these high molecular weight forms of Farlp (Fig. 8, lane 3), showing that they were ubiquitinated. U biquitination in vitro was dependent on Cdc34p (Fig. 8A, lane 4) and Cdc4p (Fig. 8B). DEAE-fracti onated extracts prepared from cdc4-ts mutants failed to ubiquitinate wild-type Far1p (Fig. 8B, lane 1). Addition of purified Cdc34p (Fig. 8, lane 1) or bacul ovirus-infected insect cell lysate containing Cdc4p (Fig. 8A, lane 2 ) al one did not restore activity of the extract. However, addition of Cdc34p and Cdc4p together restored Farlp ubiquitination (Fig. 8A, lane 3). As a control, insect lysate containing Cdc28p and Cdc34p did not lead to ubiquitination of Farlp (Fig. 8A, lane 4). U biquitination of Far1p was also dependent on the addition of the $G_{1}$ cyclin $\mathrm{CIn} 2 \mathrm{p}$ (Fig. 8A, lane 5), indicating that Far1p may need to be phosphorylated by $C d c 28 p-C \ln 2 p$ to be recognized by the Cdc34p-ubiquitination system. Alternatively, Cdc28p-CIn2p may be necessary to activate a component of the ubiquitination machinery. Importantly, no ubiquitination could be detected on Far1-22p (Fig. 8A, lane 7), suggesting that the increased half-life of Far1-22p in vivo results from its failure to be ubiquitinated. These results show that wild-type Far1p, but not Far1-22p, is ubiquitinated in a Cdc34p- and Cdc4p-dependent manner in vitro and further suggest that ubiquitination of Farlp may require a phosphorylation event governed by the $\mathrm{Cdc} 28 \mathrm{p}-\mathrm{Cln} 2 \mathrm{p}$ kinase.
Wild-type Far1p, but not Far1p-22p, is phosphorylated on Ser-87 by C dc28p-CIn2p

We have shown previously that Far1p is phosphorylated in vivo in a Cdc28p-dependent manner (Peter et al. 1993; Tyers and Futcher 1993). To determine whether Farlp was directly phosphorylated by $\mathrm{Cdc} 28 \mathrm{p}-\mathrm{CIn} 2 \mathrm{p}$ kinase in vitro, Farlp fused to glutathi one S-transferase (GST) was expressed in Escherichia coli and phosphorylated with Cdc28p-CIn2p immunoprecipitated from yeast (Fig. 9A, lane 3). As shown in Figure 9A, full-length Farlp was readily phosphorylated, whereas no phosphorylation could be detected on GST al one (Fig. 9, lane 2) or in the absence of substrate (Fig. 9, lane 1). A fragment encompassing amino acids 50-340 of wild-type Farlp (Farlp ${ }^{50-}$ 340) fused to GST was phosphorylated (Fig. 9A, lane 4), whereas little phosphate was incorporated into the same segment of Far1-22p (Fig. 9A, lane 5), showing that Far1$22 p$ could not be fully phosphorylated by $C$ dc $28 p-C \ln 2 p$ kinase. Subcl oning and sequencing of the FAR 1-22 allele reveal ed that Ser-87 was mutated to a proline residue (Fig. 9B). In the wild-type Farlp, Ser-87 is followed by a proline residue and, therefore, conforms to the minimal consensus sequence for both CDKs and MAP kinases (Nigg 1995). Therefore, we tested whether Ser-87 was indeed a phosphorylation site for $C \mathrm{dc} 28 \mathrm{p}-\mathrm{Cln} 2 \mathrm{p}$ in vitro. Phosphoamino acid anal ysis confirmed that in wild-type Far1p ${ }^{50-340}$ phosphate was predominantly incorporated on a serine residue (Fig. 9C, top panel). In contrast, when Ser-87 was mutated to a threonine residue (S87T), phosphorylation occured predominantly on threonine (Fig. 9C, bottom panel), showing that Ser-87 was the major phosphorylation site for Cdc28p-Cln2p in vitro. Fulllength Far1-22p still migrated slower on SDS gels, however, when compared with unphosphorylated Farlp, indicating that Ser-87 was not the only phosphorylation site on Far1p in vivo. N everthel ess, mutation of Ser-87 to a nonphosphorylatable residue resulted in a nonubiquitinated and stable Farl protein in vivo. Taken together, we propose that phosphorylation of Ser-87 and possibly other residues by $\mathrm{Cdc} 28 \mathrm{p}-\mathrm{CInp}$ kinase serves as a recognition signal for ubiquitination and subsequent degradation of Farlp (Fig. 10).

\section{Discussion}

Farlp is degraded in a cell cycle-dependent manner

Farlp accumulates during the $\mathrm{G}_{1}$ phase of the cell cycle. This expression pattern is achieved in part by transcriptional regulation of FAR 1 , which is restricted to $G_{1}$ and late $M$ phase of the cell cycle (M cKinney et al. 1993). We have found that even when Far1p is expressed from constitutive promoters, however, it is still detectable only in $\mathrm{G}_{1}$ cells, because Far Ip is rapi dl y degraded at stages other than $G_{1}$. The observation that a nondegradable mutant form of Farlp is present throughout the cell cycle excludes the possibility that translation of FARI RNA is restricted to $G_{1}$, as is the case for the mammalian CKI p27 (Hengst and Reed 1996). We show that Farlp is de- 


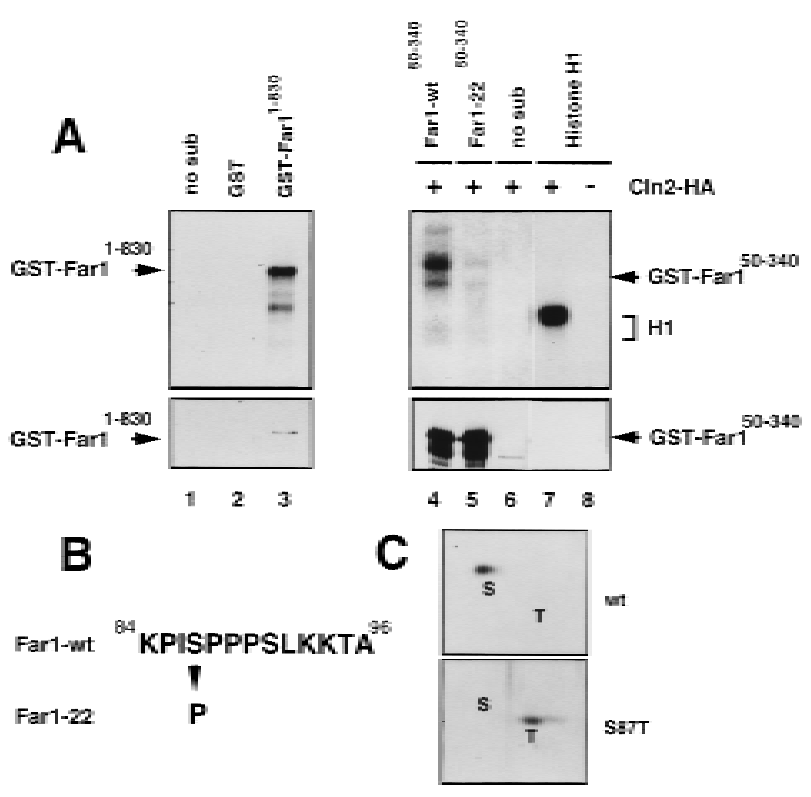

Figure 9. Far1p is phosphorylated by $C \mathrm{dc} 28 \mathrm{p}-\mathrm{CIn} 2 \mathrm{p}$ kinase on Ser-87 in vitro. (A) Full-length wild-type Farlp was produced in E. coli, purified as a GST fusion protein and phosphorylated in vitro with $\mathrm{Cdc} 28 \mathrm{p}-\mathrm{CIn} 2 \mathrm{p}$ kinase immunoprecipitated from yeast extracts (lane 3 ). As a control, the kinase assays were performed with GST al one (lane 2) or without substrate (lane 1). Phosphorylated proteins were analyzed by autoradiography (top left panel) and immunoblotting with specific antibodies against Farlp (bottom left panel). The arrowhead marks the position of GST-Far1 protein. A fragment containing amino acids 50-340 of either wild-type Far1p (lane 4) or Far1-22p (lane 5) was expressed as a GST fusion protein in E. coli and phosphorylated in vitro by immunopreci pitated $\mathrm{Cln} 2-\mathrm{HAp}$-associated kinase. Kinase reactions were also carried out with histone $\mathrm{H} 1$ (lane 7) or in the absence of substrate (lane 6). The specificity of the immunoprecipitated CIn2p-associated kinase was confirmed by including an untagged CIn2p (lane 8). The addition of equal amounts of GST-Farlp in the kinase reactions was verified by immunoblotting with antibodies against Farlp (bottom right panel). The arrowhead points to the position of the GST-Far1 ${ }^{50-340}$ protein; the bracket marks the position of phosphorylated histone $\mathrm{H} 1$. (B) Sequencing of the FAR1-22 allele uncovered a single mutation that changes Ser-87 to proline. N ote that Ser-87 is followed by a proline residue and is, therefore, a potential CDK phosphorylation site (Nigg 1995). (C) Ser-87 is phosphorylated by $\mathrm{Cdc} 28 \mathrm{p}-\mathrm{Cln} 2 \mathrm{p}$ kinase in vitro. A fragment containing amino acids 50-340 of either wild-type Far1p (top panel) or Far1p-S87T, in which Ser-87 was replaced by a threonine residue (bottom panel), was phosphorylated in vitro by immunoprecipitated CIn2-HAp-associated kinase and phosphoamino acid analysis was performed. (S) The position of phosphoserine; $(T)$ The position of phosphothreonine.

graded at the $G_{1}$ to $S$ transition and remains unstable until cells exit from mitosis. Cells overexpressing a form of Farlp that fails to be degraded accumulate predominantly at Start and not in S phase or mitosis, which is consistent with previous in vitro assays indicating that Far1p inhi bits Cdc28p complexed with $\mathrm{G}_{1}$ cyclins but is a poor inhibitor of S phase or M phase Cdks (Peter and Herskowitz 1994b).
Farlp is a yeast CKI that is required to arrest the cell cycle in the presence of mating pheromones but is not necessary for normal cell cycle progression (Chang and Herskowitz 1990). The degradation of Farlp is physiologically relevant during yeast mating. Cells arrested with $\alpha$-factor that are unable to find a mating partner adapt to the presence of mating pheromones and resume cell division (Sprague and Thorner 1992). Re-entry into the cell cycle requires the degradation of Farlp: Cells that produce nondegradable Farlp were unable to properly activate the C dc28p-CInp kinase after rel ease from $\alpha$-factor and, as a consequence, failed to recover efficiently.

Farlp degradation by the $\mathrm{G}_{1}-\mathrm{S}$ ubiquitination system requires phosphorylation of Ser-87

Two ubiquitin-dependent degradation systems trigger key transitions during the eukaryotic cell cycle. The onset of $\mathrm{S}$ phase is initiated by the proteolysis of $\mathrm{p} 40^{\text {sic1, }}$, which invol ves the $G_{1}-S$ ubiquitination system, whereas the onset of anaphase requires the anaphase-promoting complex (APC), which degrades inhibitors of sister chromatid separation (Nasmyth 1996). Substrates for the APC typically contain a short sequence termed the destruction box, which is both necessary and sufficient for degradation (King et al. 1996). Substrates for the $G_{1}-S$ ubiquitination system do not contain such a destruction box, and it is currently unknown how these proteins are recognized. The amino-terminal 50 amino acid residues of Farlp are required for its degradation in vivo (M cKinney and Cross 1995). It is unlikely, however, that these 50 amino acid residues comprise a destruction signal per se, but they contain a functional nucl ear local ization signal and a truncated Far1 protein lacking these 50 amino acids found predominantly in the cytoplasm (M. Peter, unpubl.). Because Cdc34p is localized in the nucleus (Goebl et al., 1994), cytoplasmic local ization may result in stabilization of Farlp. In contrast, failure to degrade Far1-22p is not caused by mislocalization, because Far1$22 p$ still localized to the nucleus. Recent evidence suggests that phosphorylation might provide a signal for

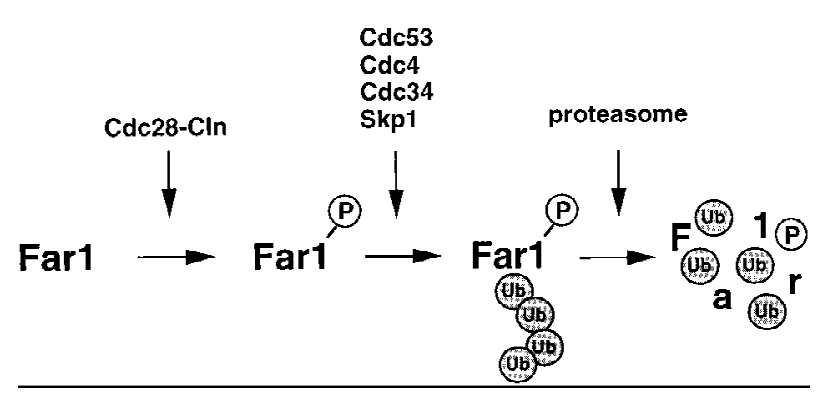

Figure 10. A model for the degradation of Farlp. Farlp binds to the Cdc28p-CInp kinase, which in turn phosphorylates Far1p on Ser-87. Phosphorylated Farlp is recognized by the ubiquitination machinery composed of Cdc34p, Cdc53p, Cdc4p, and Skplp, which ubiquitinates Farlp. U biquitinated Farlp is then degraded by the proteasome. 
ubiquitination and degradation by the $\mathrm{G}_{1}-\mathrm{S}$ destruction system (Deshai es 1997). M utations that inactivate phosphorylation sites of the $G_{1}$ cyclin $C \ln 2 p$ in yeast or mammalian cyclin $\mathrm{E}$ stabilize these proteins in vivo (Clurmann et al . 1996; Lanker et al. 1996; Won and Reed 1996). Furthermore, phosphorylated, but not unphosphorylated, CIn2p specifically interacts with Cdc53p (Willems et al. 1996). Several lines of evidence indicate that degradation of Farlp al so requires phosphorylation that may be achieved by the Cdc28p-CInp kinase. First, degradation of Farlp occurs when cells progress through Start, concomitant with the activation of the Cdc28pCInp kinase. Second, Farlp is phosphorylated in vitro and in vivo by Cdc28p-CInp kinase (Peter et al. 1993; Tyers and Futcher 1993). Third, Farlp is stable in cells harboring a temperature-sensitive mutation of CDC28 (Oehlen and Cross 1994; M. Peter and S. Henchoz, unpubl.). Fourth, we have shown that ubiquitination of Farlp in vitro requires active Cdc28p-CInp kinase. Finally, mutation of a site phosphorylated by Cdc28pCIn2p kinase stabilizes Far1p in vivo and prevents its ubiquitination. Taken together, we propose the following model for the degradation of Farlp (Fig. 10). Farlp binds to the Cdc28p-CInp kinase, which in turn phosphorylates Far $1 p$ on Ser-87 and possibly other residues. Phosphorylated Farlp is then recognized by the $G_{1}-S$ ubiquitination system composed of Cdc34p, Skplp, Cdc53p, and Cdc4p, which ubiquitinates Farlp. U biquitinated Farlp is subsequently degraded by the 26S proteasome. It remains to be shown whether Farlp is ubiquitinated in vivo. Despite the use of a mutant ubiquitin (U bK 48R, G 76A), which cannot be cl eaved by ubiquitindeconjugating enzymes (Hodgins et al. 1992; Willems et al. 1996), we were unable, so far, to convincingly show covalently attached ubiquitin on Farlp in vivo. We cannot, therefore, rigorously exclude the possibility that degradation of Farlp in vivo does not requi re ubiquitination of Farlp itself but might involve a ubiquitinated protein that targets Farlp to the proteosome.

A similar pathway has been proposed for controlling degradation of the CKI p40 ${ }^{\text {Sic1 }}$ (Deshaies 1997). Analogous to Far1p, an essential requirement for ubiquitination and degradation of $\mathrm{p} 40^{\mathrm{Sicl}}$ appears to be phosphoryIation by the $\mathrm{Cdc} 28 \mathrm{p}-\mathrm{C}$ Inp kinase, thereby ensuring that $S$ phase cannot be initiated before the $G_{1}$-specific kinase Cdc28p-CIn1p (or CIn2p) has been activated (Tyers 1996; Schneider et al. 1996; Verma et al . 1997b). Whereas available results strongly support a function of the Cdc28p-CInp kinase in the recognition of the substrate, they do not exclude the possibility that Cdc28p-CInp kinase might also directly regulate the activity of the $\mathrm{G}_{1}-\mathrm{S}$ ubiquitination system. At least two lines of evidence, however, argue against the latter interpretation. First, it is unlikely that $\mathrm{Cdc} 28-\mathrm{Cln} 2 \mathrm{p}$ is required to activate a component in the extract other than the substrate because $\mathrm{p} 40^{\mathrm{Sicl}}$ is ubiquitinated in vitro in the absence of $\mathrm{CIn} 2 \mathrm{p}$ provided that $\mathrm{p} 40^{\mathrm{Sic1}}$ is phosphorylated by $C d c 28 p-C I n 2 p$ prior to addition to the extract ( $R$. Verma and R.J. Deshares, unpubl.). Second, mutations in Farlp that prevent phosphorylation by $\mathrm{Cdc} 28 \mathrm{p}-\mathrm{CIn} 2 \mathrm{p}$ kinase also disrupt ubiquitination, suggesting that phosphorylation of the substrate is essential for ubiquitination.

The activity of the $C d c 28 p-C \ln 1(2) p$ kinase is re stricted to an interval between Start and the initiation of $\mathrm{S}$ phase, and thus correl ates with the abrupt disappearance of Far1p and p40 ${ }^{\text {Sicl }}$ (N asmyth 1993). The degradation machinery for Far $1 p$ and $p 40^{\text {Sicl }}$, however, remains fully active throughout the $G_{2}$ and $M$ phases of the cell cycle, as indicated by the $G_{1}$-specific presence of Farlp expressed from a constitutive promoter (Figs. 3C and 4). How is degradation maintained during phases at which Cdc28p-CIn1(2)p kinase activity is low? The stability of Far1-22p throughout the cell cycle indicates that degradation of Farlp in $G_{2}$ is still dependent on phosphorylati on of Ser-87. We propose that in $G_{2}$, a kinase other then Cdc28p-CIn1(2)p-perhaps Cdc28p complexed with $\mathrm{CIn3p}$ or Clbp cyclins-can phosphorylate Farlp on this site.

\section{Far1p and Cdc28p-CInp kinase antagonize each other}

Farlp was identified because it is able to inhibit the activity of the Cdc28p-CInp kinase (Chang and Herskowitz 1990; Peter and Herskowitz 1994a). Our results now show that $\mathrm{Cdc} 28 \mathrm{p}-\mathrm{CIn} 2 \mathrm{p}$, in turn, inhibits Far1p by triggering its degradation, thus establishing a negative feedback loop between Farlp and the C dc28p-CInp kinase (Cross 1995; Peter 1997). Such a negative feedback loop might serve to amplify small differences between the activities of Farlp and C dc28p-CInp kinase. It appears, therefore, that the balance between the activity of the $G_{1}$ kinase Cdc28p-CInp and its inhibitor Farlp determines whether a cell divides or arrests. The activity of the $\mathrm{G}_{1}$ kinase $\mathrm{Cdc} 28 \mathrm{p}-\mathrm{CInp}$ sets a threshold that inhibitors such as Farlp must overcome to arrest cells at Start. In the absence of pheromones, Farlp is turned over rapidly by ubiquitin-dependent proteolysis, thereby preventing accumulation of Farlp to levels sufficient to inhibit Cdc28p-CInp and allowing cell cycle progression. The balance of Far $1 p$ relative to $C d c 28 p-C I n 1(2) p$ can be ti pped by production of a stable Farlp or by activation of the pheromone response pathway. The pheromone re sponse pathway decreases the levels of the $G_{1}$-cyclins CIn1p and CIn2p (Wittenberg et al. 1990) and increases the levels of Far1p (Chang and Herskowitz 1990; Oehlen et al. 1996). Overexpression of the $G_{1}$-cyclin $C I n 2 p$, either by strong promoters or by stabilization of the protein, increases the threshold level set by the $G_{1}$ kinase, causing cells to arrest poorly in response to pheromones (Lanker et al . 1996). Cell cycle arrest can befully restored by simultaneous overexpression of Farlp (S. Henchoz and $M$. Peter, unpubl.).

Farlp level s are increased in response to mating pheromones by transcriptional activation of the FAR1 gene (Chang and Herskowitz 1990) and possibly by preventing Farlp degradation. Preliminary results indicate that the half-life of Farlp is increased after treating cells with $\alpha$-factor by a mechanism that is dependent on the MAP kinase Fus3p (S. Henchoz and M. Peter, unpubl.). It is interesting to note that other MAP kinase signal trans- 
duction pathways might similarly regulate ubiquitin-dependent proteolysis. For example, activation of a MAP kinase-signaling cascade in Xenopus eggs prevents degradation of B-type cyclins, which leads to cell cycle arrest in metaphase of meiosis II (Minshull et al. 1994). Likewise, the spindle checkpoint activates a M AP kinase cascade resulting in cell cycle arrest by preventing the scheduled degradation of mitotic cyclins and possibly other destruction box substrates (Hardwick et al. 1996). Finally, the proto-oncogene c-Jun is protected from ubiquitin-dependent degradation after phosphorylation by MAP kinases (Musti et al. 1997). It appears, therefore, that several signaling pathways might control the stability of downstream regulators by preventing their ubiquitin-dependent degradation.

U biquitin-dependent degradation: a general mechanism to regulate CKIs?

CKIs from other species might similarly be regulated by ubiquitin-dependent proteolysis (Peter 1997). The halflife of p27 ${ }^{\mathrm{Kipl}}$ increases upon contact inhibition of cells and decreases when HeLa cells are arrested in S phase (Hengst and Reed 1996). Consistent with these results, S phase extracts prepared from Swiss 3T 3 cells degrade p27 ${ }^{\text {Kip1 }}$ in vitro whereas mid-G $_{1}$ extracts do not (Brandeis and Hunt 1996). Furthermore, p27 ${ }^{\mathrm{Kip} 1}$ protein levels decrease when cells enter the cell cycle from quiescent state or in response to rapamycin (N ourse et al. 1994). Extracts prepared from proliferating cells ubiquitinate $\mathrm{p} 27^{\mathrm{Kipl}}$ protein at higher rates than extracts prepared from quiescent cells (Pagano et al. 1995). Recent studies indicate that the signal for ubiquitination and subsequent degradation of p27 ${ }^{\mathrm{Kipl}} \mathrm{might}$ also be phosphorylation. Mutations that affect putative sites of phosphorylation by associated C dk2-cyclin E kinase stabilize p27 ${ }^{\text {Kip1 }}$ in vivo (Sheaff et al. 1997; Vlach et al. 1997). Finally, increased proteosome-mediated degradation of $\mathrm{p} 27^{\mathrm{Kip} 1}$ has been observed in certain tumors and correlates with poor prognosis (Loda et al. 1997), suggesting that the ubiquitin-dependent degradation pathway may be involved in tumorogenesis. U biquitin-dependent degradation triggered by phosphorylation may represent a conserved mechanism to regulate the activity of CKIs through the cell cycle and in response to extracellular signals.

\section{Materials and methods}

Yeast strains

Yeast strains are described in Table 1. Standard yeast growth conditions and genetic manipulations were used as described (Rose and Fink 1990). Y east transformations were performed by the lithium acetate procedure (Ito et al. 1983).

DNA manipulations

Standard procedures were used for recombinant DN A manipulations (Ausubel et al. 1991; Sambrook et al. 1989). PCR was performed with Vent polymerase ( $\mathrm{N}$ ew England Biolabs). PCR products were purified with the Wizard PCR purification kit according to the instructions of the manufacturer (Promega). Site directed mutagenesis was carried out by use of M 13 mutagenesis as recommended by the manufacturer (Amersham). DNA sequencing was performed on both strands with the Sequenase kit (United States Biochemical Corp.).

Isolation of FAR1-22 (pTP63)

An amino-terminal fragment of FAR 1 was mutagenized by PCR (Leung et al. 1989) by use of the primers oTP52 (5'-GCGCTCGAGATGAAGACACCAACAAGAGTTTCG-3') and oTP55 (5'-CCGCACGGTACCCATAACATGTTCACCACC-3') and plasmid pTP62 (pGAL-FAR1) as a template. The PCR product was digested with $\mathrm{Xhol}$ and $\mathrm{Kpnl}$, ligated into the vector pTP62, which had been digested with Xhol and Kpnl, and transformed into DH $5 \alpha$. Transformants were pooled, and the isolated plasmid DNA transformed into the yeast strain K699. Individual yeast transformants were patched on SD-URA plates and subsequently replica-plated onto GAL-URA medium. Plasmids from transformants unable to grow on GAL-URA were isolated and the FARI coding sequence subcloned into Bluescript $\mathrm{KS}^{+}$ vector for sequencing. The Xhol-Sphl fragment of FAR1-22 was ligated into the Xhol-Sphl sites of pTP62 to yield plasmid pTP63.

Construction of integrating plasmids for Farlp and Far1-22p

For integration of wild-type FAR 1 and FAR1-22 expressed from the GAL promoter, the entire FAR 1 coding sequence with the GAL1 promoter was isolated from pTP62 and pTP63, respectively, after digestion with Pvull. The fragments were then Iigated to Pvull-cut pRS304 (Sikorski and Hieter 1989) to yield plasmid pTP69 (wild-type FAR1) or pTP70 (FAR1-22). The plasmids were digested with Bsu36l to target integration to the TRP1 locus.

\section{Construction of epitope-tagged versions of Farlp}

An EcoRI site was introduced by PCR at the stop codon of FAR1 by use of pTP62 as a template and primers oTP322 (5'-TGTTTGAATTTGTCGCATGCTGATGGG-3') and oTP323 (5'-CGAAGAATTCGAGGTTGGGAACTTCCAGGGTCTGATGGATCCTTTGCTG-3'). The PCR fragment digested with EcoRI and Sphl was isolated. A fragment of FAR1, which includes the GAL1 promoter was obtained after digesting PTP62 or pTP63 with Notl and Sphl. The coding sequence of GFP harboring the S65T mutation (Heim et al. 1995) was isolated as an EcoRI-BamHI fragment. The three fragments were then ligated into the $\mathrm{Notl}$ and BamHI sites of pRS316 (Sikorski and Hieter 1989) to yield pTP68 (GAL-FAR1-GFP) and pTP91 (GAL-FAR1-22-GFP). pTP68 complemented the mating and cell cycle arrest defects of far $1 \Delta$ cells (K2180).

The FAR1-lacZ fusions expressed from the GAL10 promoter were created after ligation of the Xhol-Sphl fragment of PT P62 or pTP63 into the Fusionator plasmid (pS)101, Barral et al. 1995), which was digested with Xhol and Sphl to yield pBC 1 and $\mathrm{pBC} 2$, respectively. $\mathrm{pBC} 1$ complemented the cell cycle arrest defect of farls cells (K2180).

\section{Antibodies and Western blots}

Cell extracts were prepared as described previously (Peter et al. 1993). Proteins were separated by SDS-PAGE and el ectrobl otted to nitrocellulose (Schleicher $\&$ Schuell) by use of the Minigel system (Bio-Rad Labs, Hercules, CA). Blots were probed with 
Table 1. Yeast strains

\begin{tabular}{|c|c|c|}
\hline Strain & Genotype & Source \\
\hline IH1792 & MATa cryl lys1 & collection \\
\hline $\mathrm{IH} 1793$ & MAT $\alpha$ Iys1 & collection \\
\hline $\mathrm{IH} 2518$ & MATa ura3 leu2 trp1 his4 cyh2 bar1 & $\begin{array}{l}\text { F. Cross (Rockefeller } \\
\text { University, N ew York, NY) }\end{array}$ \\
\hline $\mathrm{IH} 2517$ & MATa ura3 leu2 trp1 his4 cyh2 bar1 daf1::8xDAF1-1-URA3 & F. Cross \\
\hline K699 & MATa ade2-1 trp1-1 can1-100 leu2-3,112 his3-11,15 ura3, GAL ${ }^{+}, \mathrm{psi}^{+}$, ssd1-d2 & $\begin{array}{l}\text { K. N asmyth (IMP, Vienna, } \\
\text { Austria) }\end{array}$ \\
\hline K700 & MAT $\alpha$ ade2-1 trp1-1 can1-100 leu2-3,112 his3-11,15 ura3 $\mathrm{GAL}^{+} \mathrm{psi}^{+}$ssd1-d2 & K. N asmyth \\
\hline YMP562 & MATa $\alpha$ ade2-1 trp1-1 can1-100 leu2-3,112 his3-11,15 ura3 $\mathrm{GAL}^{+} \mathrm{psi}^{+}$ssd1-d2 & this study \\
\hline YMP1055 & $\begin{array}{l}\text { MATa ade2-1 trp1-1 can1-100 leu2-3,112 his3-11,15 ura3 GAL }{ }^{+} \text {psi }{ }^{+} \text {ssd1-d2 } \\
\text { FU S1-lacZ::LEU } 2\end{array}$ & this study \\
\hline YMP126 & $\begin{array}{l}\text { MATa ade2-1 trp1-1 can1-100 leu2-3,112 his3-11,15 ura3 } \mathrm{GAL}^{+} \mathrm{psi}^{+} \text {ssd1-d2 } \\
\text { trp1::GAL-FAR1-22-TRP1 bar1-1 }\end{array}$ & this study \\
\hline YMP127 & $\begin{array}{l}\text { MATa ade2-1 trp1-1 can1-100 leu2-3,112 his3-11,15 ura3 } \mathrm{GAL}^{+} \mathrm{psi}^{+} \text {ssd1-d2 } \\
\text { trp1::GAL-FAR1-22/ }- \text {-TRP1 bar1-1 }\end{array}$ & this study \\
\hline YMP128 & $\begin{array}{l}\text { MATa ade2-1 trp1-1 can1-100 leu2-3,112 his3-11,15 ura3 } \mathrm{GAL}^{+} \mathrm{psi}^{+} \text {ssd1-d2 } \\
\text { trp1::GAL-FAR1-TRP1 bar1-1 }\end{array}$ & this study \\
\hline K4102 & $\begin{array}{l}\text { MATa ade2-1 trp1-1 can1-100 leu2-3,112 his3-11,15 ura3 GAL }{ }^{+} \text {psi }^{+} \text {ssd1-d2 } \\
\text { cdc16 }\end{array}$ & K. N asmyth \\
\hline YMT670 & $\begin{array}{l}\text { MATa ade2-1 trp1-1 can1-100 leu2-3,112 his3-11,15 ura3 GAL }{ }^{+} \text {psi }^{+} \text {ssd1-d2 } \\
\text { cdc34-2 }\end{array}$ & $\begin{array}{l}\text { M. Tyers (Samuel Lunenfeld } \\
\text { Research Institute, Toronto } \\
\text { Ontario, Canada) }\end{array}$ \\
\hline ES464 & $\begin{array}{l}\text { MATa ade2-1 trp1-1 can1-100 leu2-3,112 his3-11,15 ura3 GAL }{ }^{+} \text {psi }^{+} \text {ssd1-d2 } \\
\text { cdc34-2 sic1::HIS3 }\end{array}$ & $\begin{array}{l}\text { C. Mann (Centre d'Etudes de } \\
\text { Saclay, Gif-sur-Y vette } \\
\text { CEDEX, France) }\end{array}$ \\
\hline YMT668 & $\begin{array}{l}\text { MATa ade2-1 trp1-1 can1-100 leu2-3,112 his3-11,15 ura3 GAL }{ }^{+} \text {psi }^{+} \text {ssd1-d2 } \\
\text { cdc4-1 }\end{array}$ & M. Tyers \\
\hline YMT740 & $\begin{array}{l}\text { MATa ade2-1 trp1-1 can1-100 leu2-3,112 his3-11,15 ura3 GAL }{ }^{+} \text {psi }^{+} \text {ssd1-d2 } \\
\text { cdc53-1 }\end{array}$ & M. Tyers \\
\hline YMT263 & $\begin{array}{l}\text { MATa ade2-1 trp1-1 can1-100 leu2-3,112 his3-11,15 ura3 } \mathrm{GAL}^{+} \mathrm{psi}^{+} \text {ssd1-d2 } \\
\text { cln2::CLN2-HA-LEU } 2\end{array}$ & M. Tyers \\
\hline Y 80 & MATa can1-100 ade2-1 his3-11,15 leu2-3,112 trp1-1 ura3-1 & $\begin{array}{l}\text { S. Elledge (Baylor College of } \\
\text { Medicine, Houston, TX) }\end{array}$ \\
\hline Y 552 & MATa can1-100 ade2-1 his3-11,15 leu2,3,112 trp1-1 ura3-1 skp1-11 & S. Elledge \\
\hline Y554 & MATa can1-100 ade2-1 his3-11,15 leu2,3,112 trp1-1 ura3-1 skp1-12 & S. Elledge \\
\hline EY 957 & $\begin{array}{l}\text { MATa ade2-1 trp1-1 can1-100 leu2-3,112 his3-11,15 ura3 } \mathrm{GAL}^{+} \mathrm{psi}^{+} \text {ssd1-d2 } \\
\text { bar1-1 }\end{array}$ & $\begin{array}{l}\text { E. Elion (Harvard University, } \\
\text { Boston, MA) }\end{array}$ \\
\hline K2149 & $\begin{array}{l}\text { MATa ade2-1 trp1-1 can1-100 leu2-3,112 his3-11,15 ura3 GAL }{ }^{+} \text {psi }^{+} \text {ssd1-d2 } \\
\text { bar1::HISG }\end{array}$ & $\begin{array}{l}\text { G. Ammerer (University of } \\
\text { Vienna, Austria) }\end{array}$ \\
\hline K2180 & $\begin{array}{l}\text { MATa ade2-1 trp1-1 can1-100 leu2-3,112 his3-11,15 ura3 GAL }{ }^{+} \text {psi }^{+} \text {ssd1-d2 } \\
\text { bar1::HISG far1::HISG }\end{array}$ & G. Ammerer \\
\hline K2297 & $\begin{array}{l}\text { MATa ade2-1 trp1-1 can1-100 leu2-3,112 his3-11,15 ura3 } \text { GAL }^{+} \text {psi }^{+} \text {dds1-d2 } \\
\text { bar1::HISG fus3::LEU } 2\end{array}$ & G. Ammerer \\
\hline YMP1054 & $\begin{array}{l}\text { MATa ade2-1 trp1-1 can1-100 leu2-3,112 his3-11,15 ura3 GAL }{ }^{+} \text {psi }^{+} \text {ssd1-d2 } \\
\text { far1::LEU } 2\end{array}$ & this study \\
\hline YMP1056 & $\begin{array}{l}\text { MATa ade2-1 trp1-1 can1-100 leu2-3,112 his3-11,15 ura3 } \mathrm{GAL}^{+} \mathrm{psi}^{+} \text {ssd1-d2 } \\
\text { far1::LEU } 2 \text { cdc34-2 }\end{array}$ & this study \\
\hline YMP1057 & $\begin{array}{l}\text { MATa ade2-1 trp1-1 can1-100 leu2-3,112 his3-11,15 ura3 } \mathrm{GAL}^{+} \mathrm{psi}^{+} \text {ssd1-d2 } \\
\text { far1::LEU } 2 \text { cdc53-1 }\end{array}$ & this study \\
\hline
\end{tabular}

monoclonal antibodies against GFP or with affinity-purified antibodies against Farlp (Peter et al. 1993) and devel oped by use of epichemiluminescence (Amersham Corp., Arlington Heights, IL).

Kinase assays and expression of GST-Farlp

GST-Farl fusion proteins to be used as substrates in the kinase reactions were expressed in E. coli and purified as described (Peter and Herskowitz 1994a). Histone H1 was purchased from
Boehringer Mannheim (No 1004 875). Cdc28p-CIn2p was immunoprecipitated from extracts as described. For in vitro phosphorylation assays, Cdc28p-CIn2p kinase was isolated from cells overexpressing CIn2-HAp or untagged $C \ln 2 p$ as a control from the constitutive ADH1 promoter (Peter and Herskowitz 1994a). Kinase assays were performed as described previously (Peter and Herskowitz 1994a).

Phosphoamino acid analysis was performed according to $\mathrm{Pe}$ ter et al. (1990). Briefly, phosphorylated proteins were eluted from SDS gels, hydrolyzed at $110^{\circ} \mathrm{C}$ for $1 \mathrm{hr}$ in $6 \mathrm{M} \mathrm{HCl}$, and the 
resulting mixture was separated in two dimensions on TLC plates.

Determination of half-life and quantification

Cells harboring plasmids encoding FAR1-GFP (pTP68) or FAR122-GFP (pTP91) were grown at $30^{\circ} \mathrm{C}$ to early log phase in raffinose-URA medium ( $2 \%$ raffinose), at which time expression was induced for $4 \mathrm{hr}$ by addition of galactose ( $2 \%$ final concentration). A first aliquot was removed before expression was turned off by addition of glucose to a final concentration of $2 \%$. Aliquots were collected every $30 \mathrm{~min}$, and Farlp levels analyzed by immunoblotting. Western blots were quantified with the Image Quant ${ }^{\mathrm{TM}}$ software (M olecular Dynamics, Inc.). The halflife of Far1p in cdc34 $\Delta$ farl (YM P1056), cdc53 $\Delta$ farl (YMP1057) or $\Delta$ farl cells (YMP1054) carrying a plasmid encoding FAR1 (pTP62) from the GAL promoter was determined as follows: cells were grown in raffinose-URA medium ( $2 \%$ raffinose) at $25^{\circ} \mathrm{C}$, at which time the expression of Farlp was induced by the addition of galactose ( $2 \%$ final). After $30 \mathrm{~min}$, the culture was shifted to $37^{\circ} \mathrm{C}$ for $2 \mathrm{hr}$, at which time the GAL promoter was repressed by the addition of glucose ( $2 \%$ final). Aliquots were collected and analyzed as described above.

\section{Determination of Far1-LacZ levels}

Transformants containing either pBC1 (GAL-FAR1-lacZ) or pBC2 (GAL-FAR1-22-LaCZ), were grown at $25^{\circ} \mathrm{C}$ in raffinoseLEU medium to early log phase at which time the temperature was shifted to $37^{\circ} \mathrm{C}$ to induce cell cycle arrest of the cdc mutants. After $90 \mathrm{~min}$, the GAL promoter was induced by addition of gal actose to $2 \%$ final concentration. Cells were harvested $2 \mathrm{hr}$ later and $\beta$-galactosidase levels were determined as described (Stern et al. 1984), except that because of the different arrest morphology, Miller units were normalized to cell number rather then $O D_{600}$. Miller units were determined from three independent experiments.

\section{Microscropy and flow cytometry}

Cells were grown as indicated, sonicated, fixed with formal dehyde to a final concentration of $3.7 \%$, and viewed by differential interference contrast microscopy. Yeast actin was visualized with rhodamin phalloidin (M olecular Probes Inc., Eugene, OR) as described previously (Peter et al. 1996).

Cells harboring plasmids encoding Farlp-GFP (pTP68) or Far1-22p-GFP (pTP91) expressed from the GAL promoter were grown in raffinose-URA medium ( $2 \%$ raffinose) at $30^{\circ} \mathrm{C}$. Expression was induced for $4 \mathrm{hr}$ by addition of galactose to $2 \%$ final concentration. GFP fluorescence was visualized with an argon laser at $488 \mathrm{~nm}$ with a Zeiss Axiovert 100 microscope (Zeiss laser Scanning M icroscope 410) with a 63×Plan-A pochromat objective (1.4 oil). Standardized conditions for the pinhole size, gain, and offset (brightness and contrast) were used for image capture. Each image was the average of eight scans. Image capture and background subtraction were performed to allow direct comparisons.

Flow cytometry was carried out as described in Epstein and Cross (1992). Briefly, cells were fixed in $70 \%$ ethanol, washed and digested with RN ase A for $5 \mathrm{hr}$. The DN A was stained then with propidium iodine and analyzed on a FACScan (BectonDickinson).

\section{U biquitination assays}

A cell free in vitro ubiquitination assay system in budding yeast has been described previously (Verma et al. 1997a,c). To sum- marize, both wild-type and mutant FAR1 (Fig. 8A) transcription templates were generated from pTP62 and pT P63, respectively, by PCR by use of a $5^{\prime}$ oligonucleotide containing a T7 RNA polymerase promoter (Verma et al. 1997a). The 5' oligonucleotide is (CCCGAATTCTTAATACGACTCACTATAGGATCCTACTTTAACGTCAAGGAG) and the $3^{\prime}$ oligonucleotide is (GCGGGATCCCTAGAGGTTGGGAACTTCCAG). Alternatively, a linearized pET 24b plasmid carrying T7-directed wildtype FAR1 with a carboxy-terminal HIS tag (provided by F. Cross) was used (Fig. 8B). The templates were then transcribed and translated in vitro according to the manufacturers instructions (Promega) to generate $\left[{ }^{35} \mathrm{~S}\right]$ methionine-labeled Farlp substrates. Both wild-type (Fig. 8A) and cdc4 (Fig. 8B) crude extracts were made from $\mathrm{G}_{1}$ cyclin-depleted cells and then fractionated on DEAE Sepharose column. The $0.25 \mathrm{M} \mathrm{NaCl}$ eluate, which lacked the endogenous Cdc34p, was used in these assays. Cdc34p was purified from E. coli as described (Banerjee et al. 1993). Cdc4p and Cdc28p were expressed in baculovirus-infected insect cells (Verma et al. 1997c). The radiolabeled substrate was incubated in $10 \mu \mathrm{l}$ of reaction mixture (Verma et al. 1997a) containing yeast extract $(100 \mu \mathrm{g})$, reaction buffer containing protease inhibitors, ATP mix, ubiquitin $(10 \mu \mathrm{g})$, and Cdc34p (100 ng). For reactions with cdc4 extracts, $0.5 \mu \mathrm{l}$ of insect lysate $(\sim 5 \mathrm{mg} / \mathrm{ml})$ containing Cdc $4 p$ or Cdc $28 p$ was used. Reactions were incubated at $24^{\circ} \mathrm{C}$ for $60 \mathrm{~min}$, terminated by the addition of SDS-PAGE sample buffer, boiled, and evaluated by SDS-PAGE and autoradiography.

\section{Pheromone response and mating assays}

$\mathrm{Hal} \mathrm{o}$ and mating assays were carried out as described previously (Valtz and Peter 1997). To measure induction of the FU S1-lacZ construct, cells (YM P1055) producing either wild-type Farlp or Far1-22p from the inducible GAL promoter for $6 \mathrm{hr}$ were exposed to $\alpha$-factor $(1 \mu \mathrm{g} / \mathrm{ml})$ for $1 \mathrm{hr}$. $\beta$-gal actosidase levels were quantified as described (Stern et al. 1984). For the $\alpha$-factor release experiments, strain K2180 producing either wild-type Far1p or Far1-22p from the GAL promoter was grown in raffinose-URA medium ( $2 \%$ raffinose) at $30^{\circ} \mathrm{C}$, at which time expression of Farlp and cell cycle arrest was induced by addition of galactose ( $2 \%$ final concentration) and $\alpha$-factor $(1 \mu \mathrm{g} / \mathrm{ml})$. After $3 \mathrm{hr}$, cells were washed twice with prewarmed GAL-URA medium (2\% galactose) and inoculated in GAL-URA medium at $30^{\circ} \mathrm{C}$ (time 0). Samples were removed every $30 \mathrm{~min}$ and protein extracts prepared as described. An al iquot of cells was fixed, sonicated and the percentage of unbudded cells was determined microscopically as described (Valtz and Peter 1997).

\section{Acknowledgments}

We thank members of the Peter and Herskowitz laboratories and B. Amati for discussions, M. Tyers, S. Elledge, G. Ammerer, E. Elion, D. Finley, J. Li, K. N asmyth, F. Cross, C. Mann, S. O'Rourke, M. Jaquenoud, and I. Davis for kind gifts of plasmids, strains, and antibodies. Thanks to R. Feldmann for providing baculovirus-expressed Cdc4p and G. Reynards for providing bacul ovirus-expressed Cdc28p. Tierry Laroche is acknowledged for help with the confocal microscope. We thank B. Amati, V. Simanis, and J. Philips for critical reading of the manuscript. This work was supported by a grant from the Swiss Cancer league, the Swiss N ational Science Foundation, and the Roche Foundation to M .P., and a research grant from the U.S. N ational Science Foundation to I.H., and a grant from the $\mathrm{N}$ ational Institutes of Health to R.J.D. (GM 52466-01). R.J.D. is a Scholar of 
the Lucille P. Markey Charitable Trust and Searle/Chicago Community Trust.

The publication costs of this article were defrayed in part by payment of page charges. This article must therefore be hereby marked "advertisement" in accordance with 18 USC section 1734 solely to indicate this fact.

\section{References}

Ausubel, F.M., R. Brent, R.E. Kingston, D.D. Moore, J.G. Seidman, J.A. Smith, and K. Struhl. 1991. Current protocols in molecular biology. Greene Publishing Associates and Wiley-Interscience, $\mathrm{N}$ ew Y ork, NY.

Bai, C., P. Sen, K. Hofmann, L. Ma, M. Goebl, J.W. Harper, and S.J. Elledge. 1996. SKP1 connects cell cycle regulators to the ubiquitin proteolysis machinery through a novel motif, the F-box. Cell 86: 263-274.

Banergee, A., L. Gregori, Y. Xu, and V. Chau. 1993. The bacterially expressed yeast $\mathrm{Cdc} 34$ gene product can undergo autoubiquitination to form a multiubiquitin chain-linked protein. J. Biol. Chem. 268: 5668-5675.

Barral, Y., S. Jentsch, and C. M ann. 1995. $G_{1}$ cyclin turnover and nutrient uptake are controlled by a common pathway in yeast. Genes \& Dev. 9: 399-409.

Brandeis, M. and T. Hunt. 1996. The proteolysis of mitotic cyclins in mammalian cells persists from the end of mitosis until the onset of S phase. EMBO J. 15: 5280-5289.

Chang, F. and I. Herskowitz. 1990. Identification of a gene necessary for cell cycle arrest by a negative growth factor of yeast: FAR1 is an inhibitor of a G1 cyclin, CLN2. Cell 63: 999-1011.

- - - 1992. Phosphorylation of Far1 in response to al pha-factor: A possible requirement for cell cycle arrest. Mol. Biol. Cell. 3: 445-450.

Ciechanover, A. 1994. The ubiquitin-proteasome proteolytic pathway. Cell 79: 13-21.

Clurmann, B.E., R.J. Sheaff, K. Thess, M. Groudine, and J.M. Roberts. 1996. Turnover of cyclinE by the ubiquitin-proteosome pathway is regulated by cdk2 binding and cyclin phosphorylation. Genes \& Dev. 10: 1979-1990.

Connelly, C. and P. Hieter. 1996. Budding yeast SKP1 encodes an evolutionary conserved kinetochore protein required for cell cycle progression. Cell 86: 275-285.

Cross, F.R. 1988. DAF1, a mutant gene affecting size control, pheromone arrest, and cell cycle kinetics of Saccharomyces cerevisiae. Mol. Cell. Biol. 8: 4675-4684.

- - . 1995. Starting the cell cycle: What's the point? Curr. Opin. Cell Biol. 7: 790-797.

Deshaies, R.J. 1997. Phosphorylation and proteolysis: Partners in the regulation of cell division in budding yeast. Curr. Opin. Genet. Dev. 7: 7-16.

Epstein, C.B. and F.R. Cross. 1992. CLB5, a novel B-cyclin from budding yeast with a role in S-phase. Genes \& Dev. 6: 16951703.

Goebl, M.G., J. Yochem, S. Jentsch, J.P. McGrath, A. Varshavsky, and B. Byers. 1988. The yeast cell cycle gene CDC34 encodes a ubiquitin-conjugating enzyme. Science 241: 1331-1335.

Goebl, M.G., L. Goetsch, and B. Byers. 1994. The U bc3 (Cdc34) ubiquitin-conjugating enzyme is ubiquitinated and phosphorylated in vivo. Mol. Cell. Biol. 14: 3022-3029.

Hardwick, K.G., E. Weiss, F.C. Luca, M. Winey, and A.W. M urray. 1996. Activation of the budding yeast spindle assembly checkpoint without mitotic spindle disruption. Science 273: 953-956.

Harper, J.W. and S.J. Elledge. 1996. Cdk inhibitors in develop- ment and cancer. Curr. O pin. Genet. Dev. 6: 56-64.

Hengst, L. and S.I. Reed. 1996. Translational control of p27(Kipl) accumulation during the cell cycle. Science 271: 1861-1864.

Heim, R., A.B. Cubitt, and R.Y. Tsien. 1995. Improved green fluoresence. Nature 373: 663-664.

Hershko, A. and H. Heller. 1985. Occurrence of a polyubiquitin structure in ubiquitin-protein conjugates. Biochem. Biophys. Res. Comm. 128: 1079-1086.

Herskowitz, I. 1995. M AP kinase pathways in yeast: For mating and more. Cell 80: 187-197.

Hochstrasser, M. 1996 U biquitin-dependent protein degradation. Annu. Rev. Genet. 30: 405-439.

Hodgins, R.W., K.S. Ellison, and M.J. Ellison. 1992. Expression of a ubiquitin derivative that conjugates to protein irreversibly produces phenotypes consistent with a ubiquitin deficiency. J. Biol. Chem. 268: 8807-8812.

Hunter, T. and J. Pines. 1994. Cyclins and cancer. II: Cyclin D and CDK inhibitors come of age. Cell 79: 573-582.

Irniger, S., S. Piatti, C. Michaelis, and K. N asmyth. 1995. Genes involved in sister chromatid separation are needed for B-type cyclin proteolysis in budding yeast. Cell 81: 269-278.

Ito, H., Y. Fukuda, K. Murata, and A. Kimura. 1983. Transformation of intact yeast cells treated with alkali cations. J. Bacteriol. 153: 163-168.

Johnson, A.D. 1995. M olecular mechanisms of cell-type determination in budding yeast. Curr. Opin. Genet. Dev. 5: 552558.

King, R.W., R.J. Deshaies, J.M. Peters, and M.W. Kirschner. 1996. How proteolysis drives the cell cycle. Science 274: 1652-1659.

Koch, C. and K. N asmyth. 1994. Cell cycle regulated transcription in yeast. Curr. O pin. Cell. Biol. 6: 451-459.

Lanker, S., M.H. Valdivieso, and C. Wittenberg. 1996. Rapid degradation of the G(1) cyclin CIn2 induced by Cdk-dependent phosphorylation. Science 271: 1597-1601.

Leberer, E., D.Y. Thomas, and M. Whiteway. 1997. Pheromone signalling and polarized morphogenesis in yeast. Curr. O pin. Genet. Dev. 7: 59-66.

Lew, D.J. and S.I. Reed. 1995. Cell cycle control of morphogenesis in budding yeast. Curr. O pin. Genet. Dev. 5: 17-23.

Leung, D.W., E. Chen, and D.V. Goeddel. 1989. A method for random mutagenesis of a defined DNA segment using a modified polymerase chain reaction. Technique 1: 11-15.

Loda, M., B. Cukor, S.W. Tam, P. Lavin, M. Fiortentino, G.F. Draetta, J.M. Jessup, and M. Pagano. 1997. Increased proteosome-dependent degradation of the cyclin-dependent kinase inhibitor p27 in aggressive colorectal carcinomas. Nature Med. 3: 231-234.

McKinney, J.D. and F.R. Cross. 1995. FAR1 and the G1 phase specificity of cell cycle arrest by mating factor in Saccharomyces cerevisiae. Mol. Cell Biol. 15: 2509-2516.

McKinney, J.D., F. Chang, N. Heintz, and F.R. Cross. 1993. Negative regulation of FAR 1 at the Start of the yeast cell cycle. Genes \& Dev. 7: 833-843.

Mendenhall, M.D. 1993. An inhibitor of p34 ${ }^{\mathrm{CDC} 28}$ protein kinase activity from Saccharomyces cerevisiae. Science 259: 216-219.

Minshull, J., H. Sun, N.K. Tonks, and A.W. Murray. 1994. A MAP kinase-dependent spindle assembly checkpoint in Xenopus egg extracts. Cell 79: 475-486.

Morgan, D.O. 1995. Principles of CDK regulation. Nature 374: 131-134.

Musti, A.M., M. Treier, and D. Bohmann. 1997. Reduced ubiq uitin-dependent degradation of c-jun after phosphorylation by MAP kinases. Science 275: 400-402. 
N asmyth, K. 1993. Control of the yeast cell cycle by the Cdc28 protein kinase. Curr. Opin. Cell. Biol. 5: 166-179.

- - . 1996. At the heart of the budding yeast cell cycle. Trends Genet. 12: 405-412.

Nigg, E.A. 1995. Cyclin-dependent protein kinases: Key regulators of the eukaryotic cell cycle. Bioessays 17: 471-480.

N ourse, J., E. Firpo, W.M. Flanagan, S. Coats, K. Polyak, M.H. Lee, J. M assague, G.R. Crabtree, and J.M. Roberts. 1994. Interleukin-2-mediated elimination of the p27 ${ }^{\mathrm{Kip} 1}$ cyclin-dependent kinase inhibitor prevented by rapamycin. Nature 372: 570-573.

Oehlen, L.J. and F.R. Cross. 1994. $\mathrm{G}_{1}$ cyclins CLN 1 and CLN2 repress the mating factor response pathway at Start in the yeast cell cycle. Genes \& Dev. 8: 1058-1070.

Oehlen, L.J., J.D. McKinney, and F.R. Cross. 1996. Stel2 and $\mathrm{Mcm} 1$ regulate cell cycle-dependent transcription of FAR1. Mol Cell Biol. 16: 2830-2837.

Pagano, M., S.W. Tam, A.M. Theodoras, P. Beer-Romero, G. Del Sal, V. Chau, P.R. Yew, G.F. Draetta, and M. Rolfe. 1995. Role of the ubiquitin-proteasome pathway in regulating abundance of the cyclin-dependent kinase inhibitor p27. Science 269: 682-685.

Peter, M. 1997. The regulation of cyclin-dependent kinase inhibitors (CKIs). Prog. Cell Cycle Res. 3: 99-108.

Peter, M. and I. Herskowitz. 1994a. Direct inhibition of the yeast cyclin-dependent kinase $\mathrm{Cdc} 28-\mathrm{CIn}$ by Far1. Science 265: 1228-1231.

- - . 1994b. Joining the complex: Cyclin-dependent kinase inhibitory proteins and the cell cycle. Cell 79: 181-184.

Peter, M., J. N akagawa, M. Dorée, J.C. Labbé, and E.A. Nigg. 1990. In vitro disassembly of the nuclear lamina and Mphase specific phosphorylation of lamins by cdc2 kinase. Cell 61: 591-602.

Peter, M ., A. Gartner, J. Horecka, G. Ammerer, and I. Herskowitz. 1993. FAR 1 links the signal transduction pathway to the cell cycle machinery in yeast. Cell 73: 747-760.

Peter, M., A.M. N eiman, H.-O. Park, M. van Lohuizen, and I. Herskowitz. 1996. Functional analysis of the interaction be tween the small GTP binding protein Cdc42 and the Ste20 protein kinase in yeast. EMBO J. 15: 7046-7059.

Rose, M.D. and G.R. Fink. 1990. Methods in yeast genetics. pp. 119-187. Cold Spring Harbor Laboratory Press, Cold Spring Harbor, NY.

Sambrook, J., E.F. Fritsch, and T. Maniatis. 1989. Molecular cloning: A laboratory manual. Cold Spring Harbor Laboratory Press, Cold Spring Harbor, N.Y.

Schneider, B.L., Q.H. Yang, and A.B. Futcher. 1996. Linkage of replication to START by the Cdk inhibitor Sicl. Science 272: 560-562.

Schwob, E., T. Bohm, M.D. M endenhal I, and K. N asmyth. 1994. The B-type cyclin kinase inhibitor $\mathrm{p} 40^{\mathrm{SIC1}}$ controls the $\mathrm{G}_{1}$ to S transition in S. cerevisiae. Cell 79: 233-244.

Sheaff, R.J., M. Groudine, M. Gordon, J.M. Roberts, and B.E. Clurman. 1997. CyclinE-CDK2 is a regulator of p27 ${ }^{\mathrm{Kip} 1}$. Genes \& Dev. 11: 1464-1478.

Sherr, C.J. 1996. Cancer cell cycles. Science 274: 1672-1677.

Sherr, C.J. and J.M. Roberts. 1995. Inhibitors of mammalian $\mathrm{G}_{1}$ cyclin-dependent kinases. Genes \& Dev. 9: 1149-1163.

Sikorski, R.S. and P. Hieter. 1989. A system of shuttle vectors and host strains designed for efficient manipulation of DNA in Saccharomyces cerevisiae. Genetics 122: 19-27.

Sprague, G.F. and J.W. Thorner. 1992. Pheromone response and signal transduction during the mating process of Saccharomyces cerevisiae. In The molecular and cellular biology of the yeast Saccharomyces cerevisiae (ed. E.W. Jones, J.R. Pringle, and J.R. Broach), pp. 657-744. Cold Spring Harbor Labo- ratory Press, Cold Spring Harbor, NY.

Stern, M., R. Jensen, and I. Herskowitz. 1984. Five SWI genes are required for expression of the $\mathrm{HO}$ gene in yeast. J. Mol. Biol. 178: 853-868.

Tyers, M. 1996. The cyclin-dependent kinase inhibitor p40 $\mathrm{sIC1}$ imposes the requirement for $\mathrm{Cln} \mathrm{G} 1$ cyclin function at Start. Proc. Natl. Acad. Sci. 93: 7772-7776.

Tyers, M. and B. Futcher. 1993. Far1 and Fus3 link the mating pheromone signal transduction pathway to three G1-phase Cdc28 kinase complexes. Mol. Cell Biol. 13: 5659-5669.

Valtz, N. and M. Peter. 1997. Functional analysis of FAR1 in yeast. Methods Enzymol. 283: 350-365.

Verma, R., Y. Chi, and R.J. Deshaies. 1997a. Cell free ubiquitination of cell cycle regulators in budding yeast extracts. Methods Enzymol. 283: 366-376.

Verma, R., R. Annan, M. Huddleston, S. Carr, G. Reynard, and R.J. Deshaies. 1997b. Phosphorylation of Siclp by $\mathrm{G}_{1}$ cyclin/ $\mathrm{Cdk}$ is required for its degradation and entry into $\mathrm{S}$ phase. Science (in press).

Verma, R., R.M. Feldman, and R.J. Deshaies. 1997c. SIC1 is ubiquinated in vitro by a pathway that requires $C D C 4$, CDC34, and cyclin/CDK activities. Mol. Biol. Cell 8: 14271437.

Vlach, J., S. Hennecke, and B. Amati. 1997. Phosphorylationdependent degradation of the cyclin-dependent kinase inhibitor p27 ${ }^{\text {Kip1. }}$ EMBO J. 16: 5334-5344.

Willems, A.R., S. Lanker, E.E. Patton, K.L. Craig, T.F. N ason, N. Mathias, R. Kobayashi, C. Wittenberg, and M. Tyers. 1996. Cdc53 targets phosphorylated $\mathrm{G} 1$ cyclins for degradation by the ubiquitin proteolytic pathway. Cell 86: 453-463.

Wittenberg, C., K. Sugimoto, and S.I. Reed. 1990. G1-specific cyclins of S. cerevisiae: Cell cycle periodicity, regulation by mating pheromone, and association with the p34 ${ }^{\mathrm{CDC} 28}$ protein kinase. Cell 62: 225-237.

Won, K.-A. and S.I. Reed. 1996. Activation of cyclinE/CDK2 is coupled to site-specific autophosphorylation and ubiquitindependent degradation of cyclin E. EMBO J. 15: 4182-4193. 


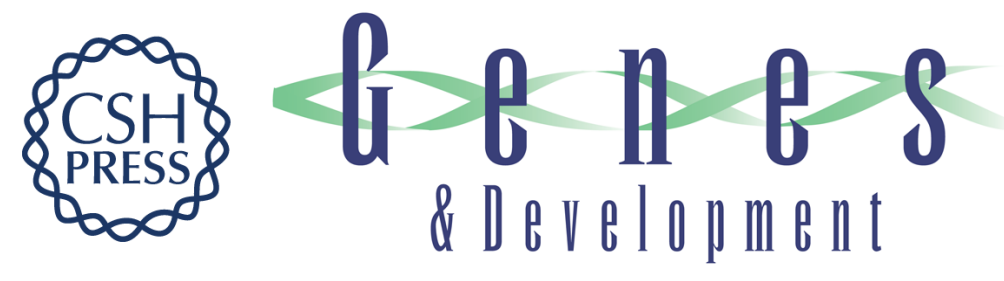

\section{Phosphorylation- and ubiquitin-dependent degradation of the cyclin-dependent kinase inhibitor Far1p in budding yeast}

Sandra Henchoz, Yong Chi, Barbara Catarin, et al.

Genes Dev. 1997, 11:

Access the most recent version at doi:10.1101/gad.11.22.3046

References This article cites 68 articles, 30 of which can be accessed free at: http://genesdev.cshlp.org/content/11/22/3046.full.html\#ref-list-1

License

Email Alerting Receive free email alerts when new articles cite this article - sign up in the box at the top Service right corner of the article or click here.

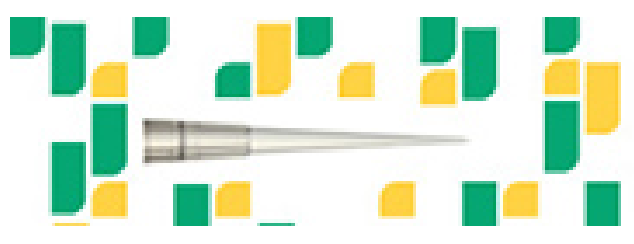

Focused on your science. 